\title{
Review \\ Mesenchymal Stem Cell-Based Therapy for Rheumatoid Arthritis
}

\author{
Madina Sarsenova 1,2, Assel Issabekova ${ }^{2}$, Saule Abisheva ${ }^{3,4}$, Kristina Rutskaya-Moroshan ${ }^{3,4}$ (D), \\ Vyacheslav Ogay 2,*(D) and Arman Saparov 1,*(D)
}

Citation: Sarsenova, M.; Issabekova, A.; Abisheva, S.; Rutskaya-Moroshan,

K.; Ogay, V.; Saparov, A.

Mesenchymal Stem Cell-Based Therapy for Rheumatoid Arthritis. Int. J. Mol. Sci. 2021, 22, 11592. https://doi.org/10.3390/ ijms222111592

Academic Editor: Vladislav Volarevic

Received: 11 October 2021

Accepted: 24 October 2021

Published: 27 October 202

Publisher's Note: MDPI stays neutral with regard to jurisdictional claims in published maps and institutional affiliations.

Copyright: (c) 2021 by the authors. Licensee MDPI, Basel, Switzerland. This article is an open access article distributed under the terms and conditions of the Creative Commons Attribution (CC BY) license (https:// creativecommons.org/licenses/by/ $4.0 /)$.
1 Department of Medicine, School of Medicine, Nazarbayev University, Nur-Sultan 010000, Kazakhstan; madina.sarsenova@nu.edu.kz

2 Laboratory of Stem Cells, National Center for Biotechnology, Nur-Sultan 010000, Kazakhstan; issabekova@biocenter.kz

3 Department of Family Medicine №1, Astana Medical University, Nur-Sultan 010000, Kazakhstan; saule_tabisheva@mail.ru (S.A.); rutskayakristina@gmail.com (K.R.-M.)

4 Department of Arthrology, National Scientific Center of Traumatology and Orthopedics, Nur-Sultan 010000, Kazakhstan

* Correspondence: ogay@biocenter.kz (V.O.); asaparov@nu.edu.kz (A.S.)

\begin{abstract}
Mesenchymal stem cells (MSCs) have great potential to differentiate into various types of cells, including but not limited to, adipocytes, chondrocytes and osteoblasts. In addition to their progenitor characteristics, MSCs hold unique immunomodulatory properties that provide new opportunities in the treatment of autoimmune diseases, and can serve as a promising tool in stem cell-based therapy. Rheumatoid arthritis (RA) is a chronic systemic autoimmune disorder that deteriorates quality and function of the synovium membrane, resulting in chronic inflammation, pain and progressive cartilage and bone destruction. The mechanism of RA pathogenesis is associated with dysregulation of innate and adaptive immunity. Current conventional treatments by steroid drugs, antirheumatic drugs and biological agents are being applied in clinical practice. However, long-term use of these drugs causes side effects, and some RA patients may acquire resistance to these drugs. In this regard, recently investigated MSC-based therapy is considered as a promising approach in RA treatment. In this study, we review conventional and modern treatment approaches, such as MSC-based therapy through the understanding of the link between MSCs and the innate and adaptive immune systems. Moreover, we discuss recent achievements in preclinical and clinical studies as well as various strategies for the enhancement of MSC immunoregulatory properties.
\end{abstract}

Keywords: mesenchymal stem cells; rheumatoid arthritis; inflammation; cell therapy; cell preconditioning; immunomodulation

\section{Introduction}

Rheumatoid arthritis (RA) is a chronic systemic disease that causes damage to joints, connective tissues, muscle, tendons, and fibrous tissue, and, as a result, has a major impact on society. Worldwide prevalence of RA is about 5 per 1000 adults. The disease is 2 to 3 times more frequently diagnosed in women than men, with a mean age of 55 years old [1,2]. The onset of the disease, also known as pre-RA phase, lasts months to years before clinical symptoms are presented and is subject to the presence of circulating autoantibodies, increased level of inflammatory cytokines and chemokines and altered cell metabolism [3]. The advanced form of the disease is characterized by severe and debilitating chronic pain that compromises patients' quality of life. Inadequate management further results in disease progression, which ultimately leads to joint erosion, destruction and deformities. Previously, more than $50 \%$ of RA patients were disabled, incapable of serving on a full-time work basis, and were subject to increased mortality. However, a better understanding of disease pathophysiology and remarkable progress in the treatment of RA have led to the 
development of more efficient treatment approaches with the improvement of the disease activity control, the degree of pain and joint damage [1,4].

Regarding therapeutic approaches in RA, currently used drugs include glucocorticoids (GCs) and synthetic and biologic disease-modifying anti-rheumatic drugs (DMARDs) [5]. In addition to these, non-steroidal anti-inflammatory drugs (NSAIDs) are the most frequently used drugs for pain relief. GCs, in combination with NSAIDs or DMARDs, are used due to their potent anti-inflammatory effects. Among the above indicated conventional treatments, DMARDs demonstrated a high potential to reduce disease symptoms and prevent disease progression in patients with RA, however, they constitute high financial costs and exhibit serious side effects [6]. Additionally, despite significant pain reduction reported in numerous randomized controlled trials, many patients still experience clinically meaningful levels of remaining pain despite the treatment, and continue to be intolerant or resistant to these therapies $[7,8]$.

Considering the limitations of conventional RA drugs, a modern cellular therapy based on mesenchymal stem cells (MSCs) may be regarded as an alternative strategy [9]. MSCs have attracted the attention of scientists and clinicians due to their capacity for self-renewal, tissue and organ regeneration and strong immunosuppressive properties. These characteristics enable suppression of the activity of pro-inflammatory cells of both innate and adaptive immune systems. It has been shown that MSCs are able to suppress the activation of natural killer (NK) cells and maturation of dendritic cells (DCs); inhibit the proliferation and function of T and B cells; promote macrophages' polarization toward an anti-inflammatory phenotype; and induce the generation of T regulatory cells (Tregs) [10]. Moreover, it was demonstrated that the immunomodulatory effect of MSCs is mediated by both cell-cell contacts and through the secretion of soluble factors [11,12]. MSCs produce transforming growth factor- $\beta$ (TGF- $\beta$ ), hepatocyte growth factor (HGF), prostaglandin E2 (PGE2), soluble form of protein HLA-G5, indolamine-2,3-dioxygenase (IDO), nitric oxide (NO) and interleukin-10 (IL-10) that are involved in the regulation and suppression of inflammatory responses [13]. All these mechanisms can contribute to controlling excessive inflammation in RA. To further improve the anti-inflammatory properties of MSCs for cell-based therapy, priming or preconditioning can be successfully applied. This approach allows for the use of bioactive substances (cytokines and growth factors), immune receptor agonists, hypoxia and 3D culturing [14]. Based on this wide range of immunomodulatory properties, the therapeutic potential of MSCs in RA treatment has been intensively studied in preclinical [15] and clinical studies [16-22]. Experimental animal models and human clinical trials demonstrated that MSCs have beneficial therapeutic effects in suppressing inflammation, bone erosion and joint destruction, as well as decreasing pannus formation through immunosuppression and immunomodulation.

In this review, we discuss current conventional therapies and the alternative therapeutic potential of MSCs for RA treatment by assessing mechanisms by which MSCs modulate the immune system and promote tissue repair. Various preconditioning strategies to enhance their therapeutic activity are reviewed as well.

\section{Current Approaches in RA Treatment}

The main goal in RA treatment is to achieve clinical remission or to reduce disease progression by inhibiting joint inflammation. Currently available conventional treatment methods include synthetic and biologic DMARDs and GCs [23].

DMARDs are the mainstay of RA therapy, which include heterogeneous drugs that inhibit disease progression and control symptoms [1]. Methotrexate (MTX), a conventional synthetic DMARD, is analogous to folic acid with anti-proliferative effects [24,25]. MTX causes the impairment of purine and pyrimidine metabolism, inhibits amino acid and polyamine synthesis and induces $\mathrm{T}$ cell and platelet apoptosis [26]. However, risks of skin cancer development and impairments in bone marrow as well as gastrointestinal, infectious, pulmonary and hematologic side effects have been observed in clinical practice $[27,28]$. 
Patients with moderate or severe disease should be initially treated with MTX as a monotherapy. In cases when disease inadequately responds to MTX, the treatment can be combined with a complementary drug, or fully replaced by other DMARDs if adverse effects are observed [29]. However, treatment with MTX is usually discontinued in less than $5 \%$ of patients due to side effects, which also can be reduced by prophylactic implementation of folates [30]. Alternative synthetic DMARDs include leflunomide, sulfasalazine, hydroxychloroquine and chloroquine. For patients with a mild disease course, hydroxychloroquine can be used as an initial therapy [31]. Leflunomide and sulfasalazine are also widely prescribed drugs for RA treatment, mostly in cases when patients have a contraindication to MTX [32]. Occasionally, a triple-drug therapy with MTX, sulfasalazine and hydroxychloroquine is applied [33]. Notably, MTX is preferred for use in patients because of its economical and therapeutic efficacy [34]. However, a combination of MTX with other drugs is reported to be a better treatment strategy than MTX alone [4,35].

The American College of Rheumatology (ACR) and European League Against Rheumatism recommend treatment with MTX in combination with short-term GC application, which is another potential anti-inflammatory drug for RA treatment for newly diagnosed patients [8,36]. The immunological effect of GCs is mediated by apoptosis of immature CD4+CD8+ thymocytes, and by the reprogramming of DCs to a tolerogenic state (tDCs). $\mathrm{tDCs}$ induce the generation of Tregs and increase macrophage phagocytosis of apoptotic cells [37-39]. However, side effects after GC application are more severe in comparison to other drugs. A dose increase in GCs causes ecchymosis, cushingoid features, parchmentlike skin, leg edema, sleep disturbance and immunosuppression. Other adverse effects involve weight gain, epistaxis, glaucoma, depression, hypertension and diabetes $[40,41]$. Despite the adverse effects of GCs, the combination of MTX and GCs could reduce RA signs in about $25 \%$ of patients within 6 months of treatment. Moreover, in conjunction with systemic administration of GCs, intra-articular (IA) injections can prevent local joint inflammation [42].

About $30-50 \%$ of patients are unresponsive to conventional DMARDs. If a 2-6 month treatment with MTX mono- or combinational therapy is inadequate, biologic DMARDs should be added [36,43]. Biologic DMARDs include tumor necrosis factor (TNF) inhibitors, costimulation modifiers, IL-6 inhibitors and B cell depleting drugs. Commercially available biological drugs, such as etanercept $\left(\right.$ Enbrel $^{\circledR}$ ), infliximab (Remicade ${ }^{\circledR}$ ), adalimumab (Humira ${ }^{\circledR}$ ), golimumab (Simponi ${ }^{\circledR}$ ) and certolizumabpegol $\left(\right.$ Cimzia $\left.^{\circledR}\right)$ are all TNF inhibitors that block cytokine signaling, reduce cell recruitment, normalize IL-6 expression level in serum and matrix metalloproteinase (MMP) expression levels in cartilage and bone, and as a result, slow bone destruction. Among the aforementioned biologic DMARDs, TNF inhibitors should be the initial drugs used in cases with an inadequate response to conventional synthetic DMARDs, and are often used in combination with other DMARDs, especially MTX [44,45]. Nonetheless, these drugs have serious side effects, such as increased risk of infections and neurological diseases, development of multiple sclerosis and lymphoma $[46,47]$. Additionally, TNF inhibition has previously resulted in the development of skin tumor Merkel cell carcinomas in patients affected by rheumatologic diseases [48]. Clinical trials with TNF inhibitors have revealed that a number of patients did not respond to treatment [49]. In this case, another DMARD, anakinra, that binds to IL-1 receptors and blocks inflammation, is considered for therapy. Anakinra is used in combination with other DMARDs or as a monotherapy, but the application is limited due to the risk of opportunistic and latent infections [50,51]. Anti-CD20 monoclonal antibody, rituximab, depletes $B$ cells and is a typical medication for the treatment of lymphomas, leukemia and autoimmune disorders, and in RA patients, it can be added when there is an insufficient response to TNF inhibitors [52]. T cell activation can be blocked by abatacept, which is the fusion protein containing the domain of cytotoxic T lymphocyteassociated antigen 4 and prevents T cell activation by binding to CD80 and CD86 receptors on antigen-presenting cells (APCs), as well as blocks interaction between DCs and T cells. A clinical study of abatacept demonstrated significant results, however some patients were 
insensitive to this treatment, which was associated with the loss of CD28 expression on T cells $[53,54]$. Another biologic DMARD, tocilizumab, blocks IL-6 receptors and significantly reduces disease severity in RA patients who have not been effectively treated with traditional DMARDs [55]. A clinical study of anti-IL-17 antibody, secukinumab, and anti-IL17RA antibody, brodalumab, has shown low response in RA patients in both cases $[56,57]$. Therapeutic efficacy of biologic DMARDs, when used as a monotherapy, is less effective compared to the combination with MTX [58].

It was shown that cytokines, such as TNF- $\alpha$, IL-1, IL-6, IL-7, IL-15, IL-17, IL-18, IL-21, IL-23, IL-32, IL-33 and granulocyte-macrophage colony-stimulating factor (GM-CSF) were implicated in the pathogenesis of RA [59]. However, clinical trials with therapeutic strategies blocking IL-1, IL-18 or IL-17 have shown few benefits. On the other hand, TNF- $\alpha$ or IL-6 targeting therapy was successful in relieving symptoms and initiating disease remission [60]. Another approach in RA therapy is targeting small molecules. The Janus kinases (JAK) inhibitors are a type of targeted synthetic DMARD that recognize and regulate the activity of the JAK family of non-receptor tyrosine kinases, which transduce signals from several different cytokine receptors through the effects on the STAT family of transcription factors. Tofacitinib represents a targeted synthetic DMARD that inhibits IL-6 production by blocking JAK1 and JAK3 through the IL-6/gp130/STAT3 signaling pathway [61], and as a result, inhibits IL-17 and interferon- $\gamma($ IFN- $\gamma)$ production and the proliferation of CD4+ T cells in patients with RA $[62,63]$. Another targeted synthetic DMARD, baricitinib, a JAK1/JAK2 inhibitor, was superior compared with the TNF- $\alpha$ antagonist adalimumab in patients with an inadequate response to the MTX [64]. Upadacitinib, which is a JAK1 inhibitor, significantly improves the efficacy of RA treatment in patients who are unresponsive to MTX or a TNF- $\alpha$ antagonist [65]. Thus, targeted synthetic DMARDs should be considered as a monotherapy or in combination with conventional synthetic DMARDs [66].

NSAIDs alongside GCs are commonly used as adjuvants to basic therapy. They are applied to decrease pain and inflammation during RA, however NSAIDs are not able to reduce bone and cartilage destruction [67]. NSAIDs are typically divided into two groups based on their chemical structure and selectivity: a group of non-selective NSAIDs, which inhibit both cyclooxygenase-1 (COX-1) and COX-2 and another group of COX-2 selective inhibitors. COX-1 plays a role in maintaining gastrointestinal mucosa lining, kidney function and platelet aggregation, whereas COX-2 is expressed during an inflammatory response. The most common NSAIDs applied in RA include acetylsalicylate, naproxen, ibuprofen and etodolac. Previously, NSAIDs were considered as first-line drugs, however low effectiveness in prevention of damage progression and side effects at high doses such as nausea, abdominal pain, ulcers and gastrointestinal bleeding, limited the implementation of these drugs [68].

Surgery is the final treatment approach for RA therapy in cases when the aforementioned nonsurgical methods are not sufficiently effective, which are becoming less frequent. Nowadays, various types of surgery are being applied, among them are tenosynovectomy, radiosynovectomy, arthroscopy, osteotomy and joint replacement. The final goal of surgical management is to relieve pain and restore joint function $[69,70]$. Table 1 summarizes the current approaches for RA treatment with the route of administration, mechanism of action and major side effects.

All of the described therapeutic strategies aim to maintain disease remission or low progression as well as reduce the risk of treatment, and thus, have relative efficacy. About $20-30 \%$ of moderate-to-severe RA patients are unresponsive to current treatment strategies [71]. In this regard, stem cell-based therapy with its immunomodulatory and immunosuppressive properties represents a promising approach in RA treatment. 
Table 1. Summary of current approaches for RA treatment.

\begin{tabular}{|c|c|c|c|c|c|}
\hline Drug & Example & Administration/Dose & Mechanism of Action & Side Effects & Reference \\
\hline \multirow{4}{*}{$\begin{array}{l}\text { Conventional } \\
\text { Synthetic } \\
\text { DMARDs }\end{array}$} & MTX & $\begin{array}{l}\text { Orally or intravenous } \\
\text { (IV) injection (15 mg), } \\
\text { single subcutaneous (SC) } \\
\text { or intramuscular (IM) } \\
\text { injection (15-25 } \\
\text { mg/week) }\end{array}$ & $\begin{array}{l}\text { Impairs purine and } \\
\text { pyrimidine metabolism, } \\
\text { inhibits amino acid and } \\
\text { polyamine synthesis }\end{array}$ & $\begin{array}{l}\text { Skin cancer and } \\
\text { gastrointestinal, } \\
\text { infectious, } \\
\text { pulmonary and } \\
\text { hematologic side } \\
\text { effects, bone } \\
\text { marrow } \\
\text { impairments }\end{array}$ & {$[27,28]$} \\
\hline & Leflunomide & $\begin{array}{l}\text { Orally (50 mg/week or } \\
10 \mathrm{mg} / \text { day) }\end{array}$ & $\begin{array}{l}\text { Inhibits dihydroorotate } \\
\text { dehydrogenase enzyme } \\
\text { leading to inhibition de } \\
\text { novo synthesis of } \\
\text { pyrimidine nucleotides }\end{array}$ & $\begin{array}{l}\text { Dyspepsia, nausea, } \\
\text { abdominal pain } \\
\text { and oral ulceration }\end{array}$ & {$[72]$} \\
\hline & Sulfasalazine & $\begin{array}{l}\text { Orally (500 mg/daily or } \\
1 \mathrm{~g} / \text { day in } 2 \text { divided } \\
\text { doses up to a maximum } \\
\text { of } 3 \mathrm{~g} / \text { day in divided } \\
\text { doses) }\end{array}$ & $\begin{array}{c}\text { Suppresses the } \\
\text { transcription of nuclear } \\
\text { factor- } \mathrm{B} \text { (NF- } \mathrm{NB}) \\
\text { responsive } \\
\text { pro-inflammatory genes } \\
\text { including TNF- } \alpha\end{array}$ & $\begin{array}{l}\text { Nausea, vomiting, } \\
\text { anorexia, } \\
\text { dyspepsia, male } \\
\text { infertility } \\
\text { (reversible), } \\
\text { headache and skin } \\
\text { rash }\end{array}$ & [73] \\
\hline & Hydroxychloroquine & $\begin{array}{l}\text { Orally (400 mg/day over } \\
\text { a 30-day period) }\end{array}$ & $\begin{array}{l}\text { Increases } \mathrm{pH} \text { within } \\
\text { intracellular vacuoles } \\
\text { and alters processes } \\
\text { such as protein } \\
\text { degradation by acidic } \\
\text { hydrolases in the } \\
\text { lysosome, assembly of } \\
\text { macromolecules in the } \\
\text { endosomes and } \\
\text { post-translation } \\
\text { modification of proteins } \\
\text { in the Golgi apparatus }\end{array}$ & $\begin{array}{l}\text { Retinal toxicity, } \\
\text { neuromyotoxicity }\end{array}$ & {$[74,75]$} \\
\hline \multirow[t]{2}{*}{$\begin{array}{l}\text { Biologic } \\
\text { DMARDs }\end{array}$} & $\begin{array}{l}\text { Etanercept, } \\
\text { Infliximab, } \\
\text { Adalimumab, } \\
\text { Golimumab, } \\
\text { Certolizuma- } \\
\text { bpegol }\end{array}$ & $\begin{array}{c}\text { Etanercept-SC injection } \\
\text { ( } 50 \mathrm{mg} / \text { week or } 25 \\
\mathrm{mg} / \mathrm{twice} \text { a week); } \\
\text { Infliximab-SC injection } \\
\text { (3-10 mg/kg every 4-8 } \\
\text { weeks); } \\
\text { Adalimumab-SC } \\
\text { injection ( } 25 \mathrm{mg} / \mathrm{twice} \text { a } \\
\text { week); Golimumab-SC } \\
\text { injection ( } 50 \mathrm{mg} / \mathrm{month}) ; \\
\text { Certolizumab } \\
\text { pegol-SC injection (400 } \\
\text { mg at weeks } 0,2 \text { and } 4, \\
\text { followed by } 200 \mathrm{mg} \\
\text { every } 2 \text { weeks) }\end{array}$ & $\begin{array}{l}\text { Blocks the biological } \\
\text { activity of TNF }\end{array}$ & $\begin{array}{c}\text { Infections, } \\
\text { neurological } \\
\text { diseases, } \\
\text { development of } \\
\text { multiple sclerosis } \\
\text { and lymphomas }\end{array}$ & [76] \\
\hline & Anakinra & $\begin{array}{l}\mathrm{SC} \text { injection }(75-150 \mathrm{mg} \\
\text { or } 0.04-2 \mathrm{mg} / \mathrm{kg})\end{array}$ & Binds to IL-1 receptors & $\begin{array}{l}\text { Opportunistic and } \\
\text { latent infections }\end{array}$ & [77] \\
\hline
\end{tabular}


Table 1. Cont.

\begin{tabular}{|c|c|c|c|c|c|}
\hline Drug & Example & Administration/Dose & Mechanism of Action & Side Effects & Reference \\
\hline & Rituximab & $\begin{array}{l}\text { IV injection ( } 1 \text { gm twice } \\
\text { separated by } 2 \text { weeks }) \\
\text { with MTX and IV } \\
\text { corticosteroid } \\
\text { premedication }\end{array}$ & $\begin{array}{l}\text { Anti-CD20 monoclonal } \\
\text { antibody }\end{array}$ & $\begin{array}{c}\text { Hypogammag- } \\
\text { lobulinemia, rarely } \\
\text { serious infectious } \\
\text { events }\end{array}$ & [78] \\
\hline & Abatacept & $\begin{array}{c}\text { IV injection } \\
(2-10 \mathrm{mg} / \mathrm{kg} \text { on days } 1, \\
15 \text { and } 30, \text { and then } \\
\text { every } 4 \text { weeks })\end{array}$ & $\begin{array}{l}\text { Contains the domain of } \\
\text { cytotoxic T } \\
\text { lymphocyte-associated } \\
\text { antigen } 4 \text { (CTLA-4), } \\
\text { blocks interaction } \\
\text { between DCs and T cells }\end{array}$ & $\begin{array}{l}\text { Serious infections, } \\
\text { increased risk of } \\
\text { certain } \\
\text { malignancies }\end{array}$ & [79] \\
\hline & Tocilizumab & $\begin{array}{c}\text { IV injection }(8 \mathrm{mg} / \mathrm{kg} \\
\text { once every } 4 \text { weeks }) \text { or } \\
\mathrm{SC} \text { injection } \\
(162 \mathrm{mg} / \text { week })\end{array}$ & Blocks IL-6 receptor & $\begin{array}{l}\text { Serious infections, } \\
\text { major adverse } \\
\text { cardiovascular } \\
\text { events, cancers, } \\
\text { diverticular } \\
\text { perforations, } \\
\text { hepatic diseases, } \\
\text { rarely lethal }\end{array}$ & [80] \\
\hline & Secukinumab & $\begin{array}{l}\text { SC injections } \\
(25-300 \mathrm{mg})\end{array}$ & Primarily targets IL-17A & $\begin{array}{l}\text { Nasopharyngitis } \\
\text { or infections of the } \\
\text { upper respiratory } \\
\text { tract, } \\
\text { mild-to-moderate } \\
\text { candidiasis }\end{array}$ & [81] \\
\hline & Brodalumab & SC injection (70-210 mg) & $\begin{array}{l}\text { Prevents the nuclear } \\
\text { factor kappa light chain } \\
\text { enhancer of activated B } \\
\text { cells, IL-6, IL-8, COX-2, } \\
\text { MMPs and GM-CSF }\end{array}$ & $\begin{array}{l}\text { Nasopharyngitis, } \\
\text { upper respiratory } \\
\text { tract infections, } \\
\text { arthralgia, back } \\
\text { pain, } \\
\text { gastroenteritis, } \\
\text { influenza, } \\
\text { oropharyngeal } \\
\text { pain, sinusitis }\end{array}$ & [82] \\
\hline \multirow[t]{2}{*}{$\begin{array}{l}\text { Targeted } \\
\text { Synthetic } \\
\text { DMARDs }\end{array}$} & Tofacitinib & $\begin{array}{l}\text { Orally ( } 5 \mathrm{mg} / \mathrm{twice} \\
\text { daily) }\end{array}$ & $\begin{array}{l}\text { Blocks Janus kinases } \\
\text { (JAK1 and JAK3) }\end{array}$ & $\begin{array}{l}\text { Cardiovascular } \\
\text { events, } \\
\text { neutropenia and } \\
\text { lymphopenia, risk } \\
\text { of infection (viral } \\
\text { reactivation, } \\
\text { herpes virus } \\
\text { reactivation, } \\
\text { opportunistic } \\
\text { infections) }\end{array}$ & [83] \\
\hline & Baricitinib & $\begin{array}{c}\text { Orally (4 mg/day or } \\
\text { lower dosage } 2 \text { mg/day) }\end{array}$ & Inhibits JAK1/JAK2 & $\begin{array}{l}\text { Hyperlipidemia, } \\
\text { viral reactivation, } \\
\text { deep venous } \\
\text { thrombosis and } \\
\text { pulmonary } \\
\text { embolism event }\end{array}$ & [84] \\
\hline
\end{tabular}


Table 1. Cont.

\begin{tabular}{|c|c|c|c|c|c|}
\hline Drug & Example & Administration/Dose & Mechanism of Action & Side Effects & Reference \\
\hline & Upadacitinib & $\begin{array}{l}\text { Orally (15 mg/day or } \\
\qquad 30 \mathrm{mg} / \text { day })\end{array}$ & Inhibits JAK1 & $\begin{array}{l}\text { Upper respiratory } \\
\text { tract infection, } \\
\text { nasopharyngitis, } \\
\text { and urinary tract } \\
\text { infections, } \\
\text { gastrointestinal } \\
\text { perforation }\end{array}$ & [85] \\
\hline GCs & $\begin{array}{c}\text { Dexame-thasone, } \\
\text { be-tamethasone, } \\
\text { triamcinolone, } \\
\text { prednisone, } \\
\text { prednisolone }\end{array}$ & $\begin{array}{l}\text { The addition of GCs, to } \\
\text { either standard DMARD } \\
\text { monotherapy or } \\
\text { combinations of } \\
\text { synthetic DMARDs with } \\
\text { low-dose GCs } \\
(<7.5 \mathrm{mg} / \text { day) or } \\
\text { high-dose GCs (up to } \\
15 \mathrm{mg} / \text { day) }\end{array}$ & $\begin{array}{l}\text { Directly activates or } \\
\text { represses gene } \\
\text { transcription }\end{array}$ & $\begin{array}{c}\text { Ecchymosis, } \\
\text { cushingoid } \\
\text { features, } \\
\text { parchment-like } \\
\text { skin, leg edema, } \\
\text { sleep disturbance, } \\
\text { immunosuppres- } \\
\text { sion, weight gain, } \\
\text { epistaxis, } \\
\text { glaucoma, } \\
\text { depression, } \\
\text { hypertension, } \\
\text { diabetes }\end{array}$ & {$[40,41,86]$} \\
\hline
\end{tabular}

\section{Mesenchymal Stem Cells in RA Treatment}

MSCs are adult multipotent stem cells with fibroblast-like morphology. Due to their immunomodulatory properties, MSCs are being considered for the treatment of autoimmune diseases [87]. The original definition of human MSCs is based on the presence of fibroblastlike morphology, with their ability to adhere to culture plastic and to differentiate into tissues of mesodermal origin, such as osteoblasts, chondrocytes and adipocytes. Furthermore, MSCs express CD73, CD90 and CD105 cell surface markers, but not hematopoietic and endothelial markers (CD14, CD34, CD45 and HLA-DR) [88-91]. The source of MSCs is a variety of tissues, including but not limited to, bone marrow (BM), gingiva, synovium, periosteum, adipose tissue (AT), dental pulp, umbilical cord (UC) and umbilical cord blood (UCB) [92-98]. In addition to their ability to differentiate into multiple cell lines, MSCs are capable of modulating innate and adaptive immune responses by alleviating the proinflammatory phenotype, particularly, through decreasing populations of DCs, macrophages, NK cells, B and T cells, and by promoting anti-inflammatory phenotype [11,99-102]. Depending on the environment, MSCs have the ability of polarizing and acquiring either pro-inflammatory (MSC1) or anti-inflammatory phenotypes (MSC2). In the presence of the inflammatory milieu (high levels of TNF- $\alpha$ and IFN- $\gamma$ ), which is generated by the immune cells, MSCs become activated and adopt an anti-inflammatory phenotype [11]. The mechanism of immune cell suppression by MSCs is mediated by secretion of a number of soluble factors, such as enzymes, cytokines and growth factors, including IDO, PGE2, NO, TGF- $\beta 1$, HGF, hemoxygenase (HO), COX-2, IL-6 and IL-10. The IDO secretion is presumably induced by inflammatory cytokine IFN- $\gamma$ [103]. The mechanism of action of IDO is mediated by conversion of an essential amino acid tryptophan to kynurenine, which impairs the synthesis of various cellular proteins and leads to the suppression of T cell proliferation. IDO is also considered to be involved in the generation of Tregs and tDCs induced by MSCs [104]. Moreover, factors produced by MSCs include nitric oxide synthase (iNOS), which induces the production of NO from macrophages thus inhibiting the proliferation, secretory and cytolytic functions of $\mathrm{T}$ cells. Both soluble factors function in the process of immunosuppression. However, it is demonstrated that iNOS mediates immunosuppression by mouse MSCs, while IDO plays a similar role in human MSCs [105].

Together with constitutive secretion of TGF- $\beta$ by MSCs, the environment favors generation of Tregs [13,106-111]. In the absence of an inflammatory environment (low 
levels of TNF- $\alpha$ and IFN- $\gamma$ ), MSCs may adopt a pro-inflammatory phenotype and enhance T cell responses by secreting chemokines (e.g, MIP-1a and MIP-1b, RANTES, CXCL9 and CXCL10) that recruit lymphocytes to the sites of inflammation; these chemokines bind to CCR5 and CXCR3 expressed on T cells. The levels of immune suppressive mediators, such as IDO and NO, are low when the pro-inflammatory phenotype is adopted [12,112].

The role of apoptotic MSCs for therapeutic applications have been recently investigated. A study by Galleu and colleagues demonstrated that infused MSCs undergo extensive caspase activation and apoptosis in the presence of cytotoxic cells, which is a requirement for their immunosuppressive function, in both preclinical and clinical studies [113]. The mechanism is explained by the engulfment of apoptotic MSCs by phagocytes, and the IDO production, which is ultimately necessary for mediating immunosuppression. Similar results were reported by another group. The MCSs effect is based on the hypoxiainduced activation of caspase 3-mediated apoptosis, recruitment of immune cells at the transplantation site and their further engulfment by locally circulating macrophages [114].

Thus, the mechanism of immunomodulation by MSCs is regulated by both cell-cell interactions and paracrine effect via the secretion of soluble factors. Considering the abovementioned immunomodulatory properties, MSCs are being widely investigated as a promising tool for the treatment of autoimmune diseases, including RA.

\subsection{In Vitro Studies}

In vitro studies demonstrate that MSCs are capable of modulating functions of the innate immune system cells. These cells not only induce the inflammatory process but also activate the adaptive immune system, including $\mathrm{T}$ and $\mathrm{B}$ cells [115]. In RA, B cells differentiate to produce RF and ACPAs, and participate as APCs for T cell activation [116]. However, co-culturing AT MSCs with T cells, B cells and Tregs showed a two-fold increase in the number of CD4+CD25+FoxP3 Tregs. Additionally, MSCs inhibited CD3+T cellmediated TNF- $\alpha$ secretion, upregulated IL-10 production and suppressed production of ACPAs by B cells [117].

The role of T cells is well described in an in vitro study by Vasilev and colleagues that confirmed the immunosuppressive capacity of the secretory factors produced by AT MSCs, to skew Th17/Treg balance towards Treg accumulation and also to downregulate major effector cytokine production involved in disease progression [118]. Through cellcell interactions, human AT MSCs downregulated the production of TNF- $\alpha$, IL- $1 \beta$ and IL-6 in mouse macrophages stimulated with lipopolysaccharide (LPS), and inhibited the proliferation of human primary T cells in response to mitogens [119].

Alternatively, MSCs have the ability to inhibit proliferation of effector memory T cells, which were found at high frequencies in the peripheral blood and synovial fluid of RA patients. These effector memory $\mathrm{T}$ cells are able to secrete proinflammatory cytokines, such as IFN- $\gamma$, IL-4 and IL-17. In contrast, MSCs are capable of modulating the immune response in RA by inhibiting both the proliferation of $\gamma \delta$ effector T cells and their inflammatory cytokine production [120]. The mechanism of modulation is controlled by PGE2 driven by the existence of COX-2, which is released by MSCs [121]. Such immunosuppressive activity of MSCs can be explained by an appropriate inflammatory environment developed by the immune system cells which secrete pro-inflammatory cytokines.

Further investigations on the therapeutic potential of MSCs in the treatment of RA have been intensively studied recently in experimental animal models, mainly using a collagen-induced arthritis (CIA) model in mice, and will be discussed in the next section.

\subsection{Preclinical Studies}

Preclinical studies demonstrated that allogeneic MSC administration was more beneficial than administration of autologous MSCs [122,123]. MSCs are able to suppress inflammation both through interactions with the immune system cells and through the paracrine mechanisms. The schematic illustration represents the immunomodulatory effects of MSCs and their secreted factors in RA (Figure 1). 


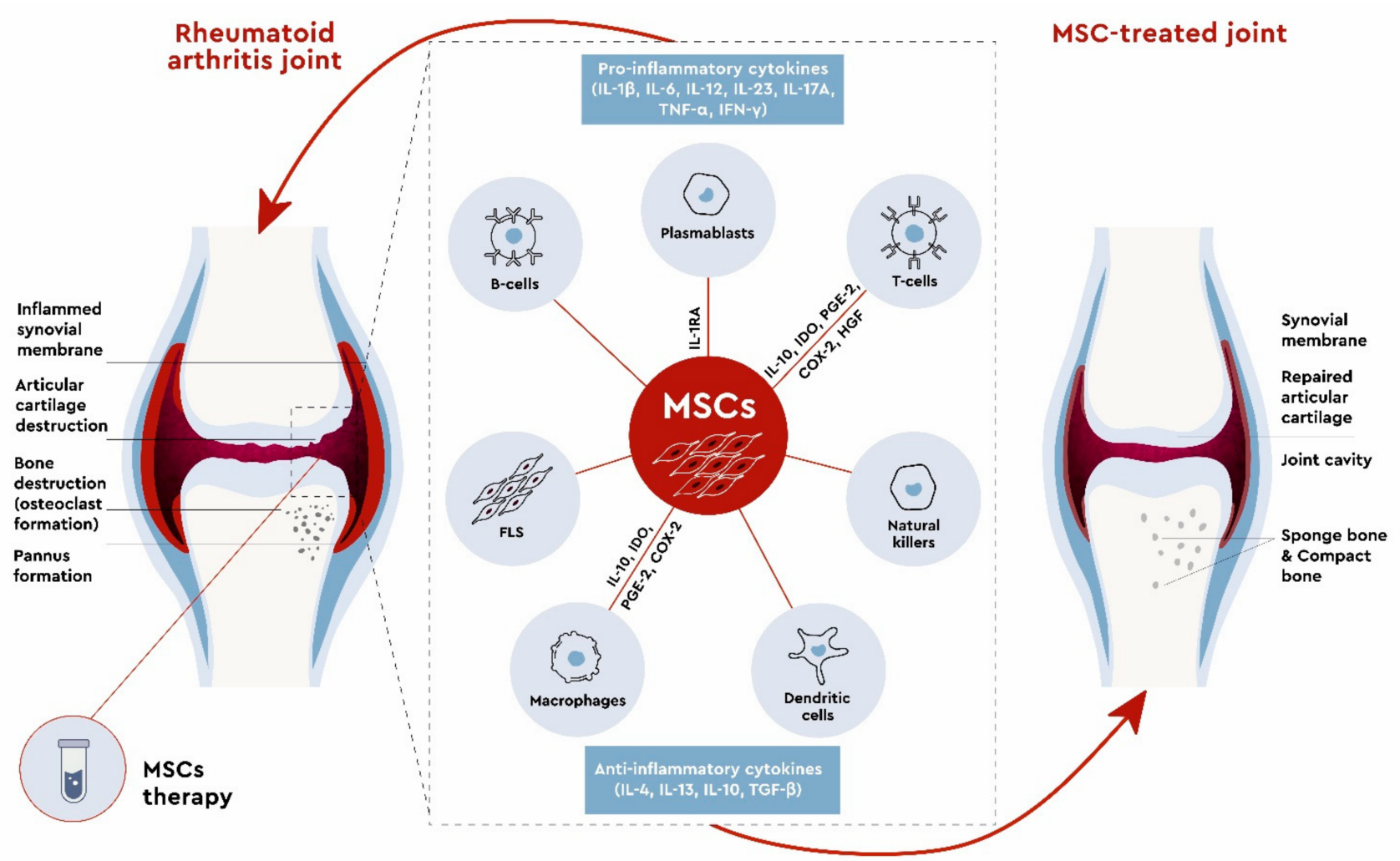

Figure 1. Immunomodulatory effects of mesenchymal stem cells and their secreted factors in rheumatoid arthritis.

Cells of the innate immune system, such as macrophages, play a very important role in RA pathogenesis. It was shown that phagocytically active, proinflammatory HLA-DR+ macrophages can be detected in the synovium of RA patients [124]. These findings indicate that synovial macrophages of RA patients can influence $T$ cell activation and subsequent migration and activation of B cells, thus generating an inflammatory response [125,126]. In this regard, MSCs have an impact on the macrophage polarization that maintains the balance between pro-inflammatory and anti-inflammatory phenotypes. MSCs constitutively produce IL-6, which either alone or in combination with LPS and/or pro-inflammatory cytokines, such as IFN- $\gamma$, polarizes pro-inflammatory M1 macrophages towards antiinflammatory IL-10-producing M2 macrophages. M2 macrophages secrete high levels of IL-10 and TGF- $\beta 1$ that suppress inflammation and promote tissue regeneration [11]. The polarization is likely initiated by a combination of cell-cell contact mechanisms and the production of soluble factors, such as IDO, PGE2, IL-10 and COX-2. For instance, UCB MSCs suppressed M1 macrophage proliferation and activated M2 macrophage production via TNF- $\alpha$-mediated activation of COX-2 and TNF-stimulated gene-6 (TSG-6). Additionally, UCB MSCs downregulated nucleotide-binding domain, leucine-rich repeat pyrin 3 (NLRP3) inflammasome-mediated IL-1 $\beta$ secretion and caspase-1 production in macrophages through IL-1 $\beta$ feedback loop in CIA mice [127]. Furthermore, osteoclast activity is upregulated in RA that further induces severe bone destruction, while in healthy conditions, osteoblast and osteoclast activity is balanced, promoting a normal level of bone formation and resorption [128]. Moreover, TNF- $\alpha$ and IL-1 $\beta$ that are secreted by pro-inflammatory macrophages cause the activation of synovial fibroblasts, which secrete the receptor activator of NF- $\mathrm{KB}$ ligand (RANKL) and macrophage colony-stimulating factor 1 (M-CSF). These factors are indispensable in osteoclast formation [129]. On this matter, AT MSCs inhibited both RANKL-induced osteoclastogenesis and decreased the osteoclast precursors in bone marrow, leading to the prevention of systemic bone loss in CIA mice [130]. 
DCs are also cells of the innate immune system that serve as a professional APC. They are characterized by a stellate morphology and high expression of MHC class II, as well as by their capacity to uptake antigens and migrate to draining lymph nodes to prime naive T cells [131]. However, in RA, DCs are also responsible for inducing inflammation by presenting antigens to autoreactive $\mathrm{T}$ cells with subsequent production of cytokines, which stimulate T-helper differentiation. The pannus developing in RA likely occurs with the involvement of circulating DCs via chemokine signaling. Although direct evidence is still lacking, several chemokine receptors expressed on DCs have been implicated in the pathogenesis of CIA. These include CX3CR1, CCR9, CXCR4 and CCR2 [131]. Additionally, in a recent study, the inhibition of CCR7-mediated DCs migration towards draining lymph nodes by administration of FTY720, an immune-modulator that is a chemical derivative of myriocin, was also shown to ameliorate CIA [132]. More detailed information on the mechanism of action of MSCs on DCs is mainly known from other autoimmune diseases, and is based on their ability to inhibit maturation of DCs and enhance the generation of tDCs by reducing Toll-like receptor (TLR) activation and suppressing IL-12 production by DCs [133]. Moreover, MSCs and tDCs have demonstrated a synergistic immunosuppressive effect in a CIA model by polarizing Th cells, inhibiting proinflammatory cytokine production and reducing cartilage degeneration [134].

Similar results on the effects of MSCs on B cells confirmed the data obtained from in vitro studies. MSCs significantly contributed to the inhibition of plasmablast generation and influenced B cell differentiation, which was mediated by IL-1 receptor antagonist (IL1RA) secreted by MSCs [99]. Based on published data, the mechanism of action of MSCs on B cells is mediated not only by direct cell-to-cell interactions, but also by soluble factors produced by MSCs.

T cells have a greater impact and play a crucial role in RA pathogenesis. MSCs have the ability to control the proliferation, differentiation and activity of $\mathrm{T}$ cells and reduce the production of pro-inflammatory cytokines. Recent studies also confirmed the regulatory capacities of MSCs. For instance, some studies demonstrated that the application of MSCs significantly decreased pro-inflammatory cytokine levels (IL-1 $\beta$, IL-6), whereas the expression level of anti-inflammatory cytokine (IL-10) increased. Furthermore, a number of Tregs also significantly increased after the human UCB MSCs treatment $[135,136]$. The analysis of CD4 T cell populations from CIA mice after treatment with human embryonic stem cell-derived (hESC) MSCs ameliorated CIA by inducing IFN- $\gamma+$ Th1 cells and IDO1 and showed an increase in the number of FoxP3+ Tregs [137]. Furthermore, human hAT MSC s treatment induced the expansion of Tregs in the peripheral blood and in the spleen [119]. Additionally, administration of hUC MSCs in a mouse CIA model prevented disease development by reducing the frequency and functions of T follicular helper cells (Tfh) through IDO activity [138]. Thus, MSCs can also suppress the differentiation of Tfh toward effector subsets, such as Tfh1, Tfh2 and Tfh17, and as a consequence, can reduce the production of autoreactive antibodies.

The pathogenic role of cytotoxic CD8+ T cells (CTLs) in RA has not been broadly investigated. However, there is evidence of a direct correlation between RA severity and the number of CTLs in the joint, where a high frequency of CD8+ T cells at the inflammation site has been observed [139]. Additionally, a recent study by Vohra and colleagues confirmed that UC MSCs downregulated the functions of activated CD4+ and CD8+ T cells from both the peripheral blood and synovial fluid of RA patients, suppressed the secretion of pro-inflammatory cytokines and induced the expansion of Tregs. Intraperitoneal (IP) injection of UC MSCs in CIA rats clearly indicated a sustained impact in terms of slowing down the progression of disease [140]. Studies showed that IV administration of hAT MSCs in CIA mice decreased GM-CSF expressing CD4+ T cells in blood and spleen, which are considered to be key effector cells in RA pathophysiology [141]. In addition, the above evidence leads to the conclusion that RA is a Th1/Th17-induced disease, and Tregs have the capacity to modulate inflammatory processes. MSCs in this regard have a balancing 
effect between Th cells and Tregs that is modulated by soluble factors, such as IDO, PGE2, IL-10, NO and HGF $[142,143]$.

Thus, it can be generalized that a sufficiently large array of data on the application and the possible immunomodulatory effects of MSCs in RA are under investigation. The existing research data differ from each other due to various specifying variables. These include the origin of MSCs (human or mouse), tissue source, route of administration, timing of treatment, number of repetitions, dosage and mouse/rat strains, which are all critical and have different effects on the therapeutic outcome. The in vivo studies related to the effects of MSCs on the cells of innate and adaptive immunity described in this section are summarized in Table 2.

It was recently demonstrated that syndecan-3 (SDC3), which is the largest cell surface molecule from the syndecan family, plays an important role in inflammatory disorders such as RA. MSCs derived from SDC3 knockout mice possessed enhanced adhesion to collagen type I and AKT pathway hyperactivation. This evidence suggests that SDC3 targeting might be a promising therapeutic strategy for RA treatment [145]. In conclusion, metaanalysis data demonstrated that MSCs were effective in RA treatment in animal models. It suggests that in preclinical studies, MSCs have consistently exhibited therapeutic benefits. Authors also reported that human UC MSCs led to significant improvements in clinical and histological scores. These data suggest that human UC MSCs could serve as the most appropriate cell source for RA treatment application [15].

Table 2. Preclinical studies for RA treatment with MSCs.

\begin{tabular}{|c|c|c|c|c|c|c|}
\hline RA Model & $\begin{array}{l}\text { Source and } \\
\text { Tissue Origin } \\
\text { of MSCs }\end{array}$ & $\begin{array}{c}\text { Route of } \\
\text { Administra- } \\
\text { tion/Number } \\
\text { of Repetitions }\end{array}$ & Dosage & $\begin{array}{l}\text { Mechanism of } \\
\text { Action }\end{array}$ & $\begin{array}{c}\text { Therapeutic } \\
\text { Outcome }\end{array}$ & Reference \\
\hline CIA in DBA1/J mice & hUCB MSCs & $\begin{array}{l}\text { IP injections for } \\
5 \text { days after the } \\
\text { RA score } \\
\text { reached } 3 \text { or } \\
\text { more }\end{array}$ & $1 \times 10^{6}$ cells & $\begin{array}{l}\text { hUCB MSCs } \\
\text { polarized M1 } \\
\text { macrophages } \\
\text { toward M2 } \\
\text { phenotype } \\
\text { through TNF- } \alpha- \\
\text { mediated } \\
\text { activation of } \\
\text { COX-2 and } \\
\text { TSG-6 }\end{array}$ & $\begin{array}{c}\text { Amelioration of } \\
\text { the severity of } \\
\text { CIA }\end{array}$ & [127] \\
\hline CIA in DBA/1J mice & hBM MSCs & $\begin{array}{l}\text { IP injection on } \\
\text { day } 22 \text { after } \\
\text { primary } \\
\text { immunization }\end{array}$ & $2 \times 10^{6}$ cells & $\begin{array}{c}\text { hBM MSCs } \\
\text { inhibited } \\
\text { RANKL- } \\
\text { induced } \\
\text { osteoclastogen- } \\
\text { esis }\end{array}$ & $\begin{array}{l}\text { Amelioration of } \\
\text { inflammation- } \\
\text { induced } \\
\text { systemic bone } \\
\text { loss in CIA }\end{array}$ & [130] \\
\hline CIA in DBA1/J mice & hUC MSCs & $\begin{array}{l}\text { IV injection } \\
\text { on day } 28 \text { after } \\
\text { RA score } \\
\text { reached } 1 \text { or } \\
\text { more }\end{array}$ & $1 \times 10^{6}$ cells & $\begin{array}{l}\text { hUC MSCs } \\
\text { reduced } \\
\text { number and } \\
\text { downregulated } \\
\text { function of Tfh } \\
\text { cells in the } \\
\text { spleen } \\
\text { accompanied } \\
\text { with decreased } \\
\text { Th1 and Th17 } \\
\text { cells }\end{array}$ & $\begin{array}{l}\text { Prevention of } \\
\text { CIA } \\
\text { progression }\end{array}$ & [138] \\
\hline
\end{tabular}


Table 2. Cont

\begin{tabular}{|c|c|c|c|c|c|c|}
\hline RA Model & $\begin{array}{l}\text { Source and } \\
\text { Tissue Origin } \\
\text { of MSCs }\end{array}$ & $\begin{array}{c}\text { Route of } \\
\text { Administra- } \\
\text { tion/Number } \\
\text { of Repetitions }\end{array}$ & Dosage & $\begin{array}{l}\text { Mechanism of } \\
\text { Action }\end{array}$ & $\begin{array}{l}\text { Therapeutic } \\
\text { Outcome }\end{array}$ & Reference \\
\hline $\begin{array}{c}\text { CIA in } \\
\text { DBA/1OlaHsd mice }\end{array}$ & hESC MSCs & $\begin{array}{l}\text { Single-dose IP } \\
\text { injection on the } \\
\text { day of } \\
\text { immunization } \\
\text { (prophylaxis) or } \\
\text { with three } \\
\text { doses of hESC } \\
\text { MSCs every } \\
\text { other day } \\
\text { starting on the } \\
\text { day of arthritis } \\
\text { onset (therapy) }\end{array}$ & $1 \times 10^{6}$ cells & $\begin{array}{l}\text { hESC MSCs } \\
\text { increased the } \\
\text { number of } \\
\text { FoxP3(+) Tregs } \\
\text { and IFN- } \gamma^{+} \text {Th1 } \\
\text { cells but not } \\
\text { Th17, } \\
\text { additionally } \\
\text { induced the } \\
\text { expression of } \\
\text { IDO1 in } \\
\text { inguinal lymph } \\
\text { nodes }\end{array}$ & $\begin{array}{l}\text { Reduction of } \\
\text { disease } \\
\text { progression and } \\
\text { severity of CIA }\end{array}$ & [137] \\
\hline CIA in DBA $1 / \mathrm{J}$ mice & hUCB MSCs & $\begin{array}{l}\text { IV injection of } \\
\text { three different } \\
\text { doses every } 2 \\
\text { weeks, overall, } \\
\text { three times }\end{array}$ & $\begin{array}{l}1 \times 10^{6} \text { cells, } \\
3 \times 10^{6} \text { cells, } \\
5 \times 10^{6} \text { cells }\end{array}$ & $\begin{array}{c}\text { hUCB MSCs } \\
\text { decreased IL-1 } \beta \\
\text { and IL- } 6 \text { levels; } \\
\text { concentration } \\
\text { of } 5 \times 10^{6} \text { hUCB } \\
\text { MSCs increased } \\
\text { the level of } \\
\text { IL-10 } \\
\text { production and } \\
\text { the expansion } \\
\text { of Tregs }\end{array}$ & $\begin{array}{l}\text { Alleviation of } \\
\text { RA symptoms } \\
\text { in a CIA model }\end{array}$ & [135] \\
\hline CIA in DBA1/J mice & hUC MSCs & $\begin{array}{l}\text { IV injection } \\
\text { after } 24 \text { days } \\
\text { after RA } \\
\text { induction }\end{array}$ & $2 \times 10^{6}$ cells & $\begin{array}{l}\text { hUC MSCs } \\
\text { reduced the } \\
\text { level of IL- } 6 \text { by } \\
80.0 \% 2 \text { days } \\
\text { after treatment } \\
\text { and by } 93.4 \% \text { at } \\
\text { the endpoint }\end{array}$ & $\begin{array}{l}\text { Relief of RA } \\
\text { disease } \\
\text { symptoms in a } \\
\text { CIA model }\end{array}$ & [136] \\
\hline CIA in DBA $/ 1$ mice & hAT MSCs & $\begin{array}{l}\text { IV injection on } \\
\text { day } 28 \text { after } \\
\text { arthritis } \\
\text { induction for } \\
\text { the next five } \\
\text { days }\end{array}$ & $2 \times 10^{6}$ cells & $\begin{array}{l}\text { hAT MSCs } \\
\text { induced the } \\
\text { expansion of } \\
\text { Tregs both in } \\
\text { the peripheral } \\
\text { blood and } \\
\text { spleen (in vivo); } \\
\text { and } \\
\text { downregulated } \\
\text { the level of } \\
\text { TNF- } \alpha \text {, IL-1 } \beta \\
\text { and IL-6 in } \\
\text { mouse } \\
\text { macrophages } \\
\text { and inhibited } \\
\text { the } \\
\text { proliferation of } \\
\text { human primary } \\
\text { T cells (in vitro) }\end{array}$ & $\begin{array}{l}\text { Attenuation of } \\
\text { systemic } \\
\text { inflammation in } \\
\text { mice with CIA }\end{array}$ & [119] \\
\hline
\end{tabular}


Table 2. Cont.

\begin{tabular}{|c|c|c|c|c|c|c|}
\hline RA Model & $\begin{array}{c}\text { Source and } \\
\text { Tissue Origin } \\
\text { of MSCs }\end{array}$ & $\begin{array}{c}\text { Route of } \\
\text { Administra- } \\
\text { tion/Number } \\
\text { of Repetitions }\end{array}$ & Dosage & $\begin{array}{c}\text { Mechanism of } \\
\text { Action }\end{array}$ & $\begin{array}{l}\text { Therapeutic } \\
\text { Outcome }\end{array}$ & Reference \\
\hline CIA in Balb/c mice & $\begin{array}{c}\text { Murine BM } \\
\text { MSCs }\end{array}$ & $\begin{array}{l}\text { IV injection of } \\
\text { MSCs and IP } \\
\text { injection of IL-4 } \\
\text { at day } 21\end{array}$ & $5 \times 10^{6}$ cells & $\begin{array}{c}\text { BM MSCs in } \\
\text { combination } \\
\text { with IL-4 } \\
\text { treatment } \\
\text { decreased the } \\
\text { levels of RF, } \\
\text { C-reactive } \\
\text { protein (CRP) } \\
\text { and } \\
\text { anti-nuclear } \\
\text { antibodies; } \\
\text { TNF- } \alpha \text { and } \\
\text { monocyte } \\
\text { chemoattrac- } \\
\text { tant protein-1 } \\
\text { (MCP-1) levels. } \\
\text { Additionally, } \\
\text { BM MSCs } \\
\text { decreased the } \\
\text { levels of } \\
\text { cartilage } \\
\text { oligomeric } \\
\text { matrix protein } \\
\text { (Comp), tissue } \\
\text { inhibitor } \\
\text { metalloproteinase- } \\
1 \text { (Timp1), } \\
\text { MMP-1 and } \\
\text { IL-1 receptor }\end{array}$ & $\begin{array}{l}\text { Reduction of } \\
\text { joint } \\
\text { inflammation, } \\
\text { synovial } \\
\text { cellularity, } \\
\text { vascularization } \\
\text { and bone } \\
\text { destruction in a } \\
\text { CIA model }\end{array}$ & [144] \\
\hline $\begin{array}{c}\text { CIA in female Wistar } \\
\text { rats }\end{array}$ & hUC MSCs & $\begin{array}{l}\text { IP injection on } \\
\text { days } 16 \text { and } 18\end{array}$ & $2 \times 10^{6}$ cells & $\begin{array}{l}\text { hUC MSCs } \\
\text { downregulated } \\
\text { the functions of } \\
\text { activated CD4+ } \\
\text { and CD8+ T } \\
\text { cells, } \\
\text { suppressed the } \\
\text { secretion of pro- } \\
\text { inflammatory } \\
\text { cytokines and } \\
\text { induced the } \\
\text { expansion of } \\
\text { Tregs }\end{array}$ & $\begin{array}{l}\text { Slowing down } \\
\text { the progression } \\
\text { of disease } \\
\text { activity }\end{array}$ & [140] \\
\hline
\end{tabular}

\subsection{Clinical Studies}

Several MSC-based therapies for the treatment of RA were studied in 18 clinical trials [146]. Currently, nine of these trials are still in progress, and the remaining clinical studies were completed and published. Clinical trials investigating the therapeutic potential of MSCs from various tissue sources were mainly focused on the evaluation of the safety and efficacy of the transplantation of MSCs in RA (Table 3). In this section, we describe some of the major clinical studies initiated during the last 10 years. 
Table 3. Clinical trials for RA treatment with MSCs.

\begin{tabular}{|c|c|c|c|c|c|c|c|c|}
\hline $\begin{array}{l}\text { Clinical Trial } \\
\text { Identifier }\end{array}$ & Study Design & Cell Source & $\begin{array}{l}\text { Number of } \\
\text { Patients }\end{array}$ & $\begin{array}{c}\text { Route of Administration and } \\
\text { Doses }\end{array}$ & $\begin{array}{l}\text { Follow-Up Time } \\
\text { (Months) }\end{array}$ & $\begin{array}{c}\text { Clinical Status } \\
\text { before Treatment } \\
\text { or Control Group }\end{array}$ & $\begin{array}{l}\text { Clinical Status } \\
\text { after Treatment }\end{array}$ & Reference \\
\hline NCT01663116 & $\begin{array}{c}\text { Randomized, } \\
\text { multicenter, } \\
\text { double-blind, } \\
\text { placebo- } \\
\text { controlled, } \\
\text { dose-escalation } \\
\text { phase Ib/IIa }\end{array}$ & $\begin{array}{l}\text { Allogeneic AT } \\
\text { MSCs }\end{array}$ & 53 & $\begin{array}{c}1,2 \text { or } 4 \times 10^{6} \text { cells } / \mathrm{kg} \text { of body } \\
\text { weight, three IV injections, } \\
\text { weekly }\end{array}$ & 6 & $\begin{array}{c}\text { DAS28-ESR } \uparrow, \\
\text { CRP } \uparrow, \\
\text { ACR20 response } \\
\text { after } 1 \text { month } \\
(29 \%) \text { and } \\
3 \text { month }(0 \%)\end{array}$ & $\begin{array}{c}\text { DAS28-ESR } \downarrow \text {, } \\
\text { CRP } \downarrow \text {, } \\
\text { ACR20 response } \\
\text { after } 1 \text { month } \\
(20-45 \%) \text { and } 3 \\
\text { month }(15-25 \%)\end{array}$ & [16] \\
\hline Unknown & Pilot & $\begin{array}{l}\text { Autologous AT } \\
\text { MSCs }\end{array}$ & 3 & $\begin{array}{c}\text { Patient 1: two separate IV } \\
\text { injections of } 3 \times 10^{8} \text { cells, } \\
15 \text { week interval } \\
\text { Patient } 2 \text { : once } 2 \times 10^{8} \text { cells (IV } \\
\text { injection) }+1 \times 10^{8} \text { cells (IA } \\
\text { injection); once } 3.5 \times 10^{8} \text { cells } \\
\text { (IV injection) }+1.5 \times 10^{8} \text { cells } \\
\text { (IA injection), 3-month interval } \\
\text { Patient 3: four separate IV } \\
\text { injection of } 2 \times 10^{8} \text { cells, } \\
\text { 4-week interval }\end{array}$ & $3-13$ & $\begin{array}{c}\text { VAS } \uparrow, \\
\text { KWOMAC } \uparrow, \\
\mathrm{CRP} \uparrow, \mathrm{RF} \uparrow, \\
\text { anti-CCP } \uparrow, \\
\text { Standing time } \downarrow \text {, } \\
\text { WD } \downarrow\end{array}$ & $\begin{array}{c}\text { VAS } \downarrow \text {, } \\
\text { KWOMAC } \downarrow \text {, } \\
\text { CRP } \downarrow, \text { RF } \downarrow \text {, } \\
\text { anti-CCP } \downarrow \text {, } \\
\text { standing time } \uparrow, \\
\text { WD } \uparrow \text {, off steroids }\end{array}$ & [17] \\
\hline NCT03333681 & Phase I & $\begin{array}{l}\text { Autologous BM } \\
\text { MSCs }\end{array}$ & 9 & $\begin{array}{l}1 \text { to } 2 \times 10^{6} \text { cells } / \mathrm{kg} \text { of body } \\
\text { weight, single IV injection }\end{array}$ & 12 & $\begin{array}{l}\text { DAS28-ESR } \uparrow, \\
\text { VAS } \uparrow, E S R \uparrow, \\
\mathrm{CRP} \uparrow, \mathrm{RF} \uparrow, \\
\text { anti-CCP } \uparrow\end{array}$ & $\begin{array}{c}\text { DAS28-ESR } \downarrow \text {, } \\
\text { VAS } \downarrow, \text { ESR } \downarrow \text {, } \\
\text { CRP } \downarrow \text { (NS), RF } \downarrow \text {, } \\
\text { anti-CCP } \downarrow \text { (NS) }\end{array}$ & [18] \\
\hline NCT01873625 & $\begin{array}{c}\text { Randomized, } \\
\text { triple-blind, } \\
\text { single-center, } \\
\text { placebo- } \\
\text { controlled phase } \\
\text { I/II }\end{array}$ & $\begin{array}{l}\text { Autologous BM } \\
\text { MSCs }\end{array}$ & 30 & $\begin{array}{c}4.2 \times 10^{7} \text { cells } / \text { patient, single } \\
\text { IA injection }\end{array}$ & 12 & $\begin{array}{c}\mathrm{DAS} 28 \uparrow, \mathrm{VAS} \uparrow, \\
\mathrm{WOMAC} \uparrow, \mathrm{ESR} \uparrow, \\
\mathrm{CRP} \uparrow, \text { Pain FWD } \downarrow \text {, } \\
\mathrm{WD} \downarrow, \text { Time to } \\
\text { jelling } \downarrow \text {, Standing } \\
\text { time } \downarrow\end{array}$ & $\begin{array}{c}\text { DAS28 } \downarrow \text { (NS), } \\
\text { VAS } \downarrow, \text { WOMAC } \downarrow \text {, } \\
\text { ESR } \downarrow \text { (NS), CRP } \downarrow \\
\text { (NS), Pain FWD } \uparrow, \\
\text { WD } \uparrow, \text { Time to } \\
\text { jelling } \uparrow, \text { Standing } \\
\text { time } \uparrow\end{array}$ & [19] \\
\hline
\end{tabular}


Table 3. Cont.

\begin{tabular}{|c|c|c|c|c|c|c|c|c|}
\hline $\begin{array}{l}\text { Clinical Trial } \\
\text { Identifier }\end{array}$ & Study Design & Cell Source & $\begin{array}{l}\text { Number of } \\
\text { Patients }\end{array}$ & $\begin{array}{c}\text { Route of Administration and } \\
\text { Doses }\end{array}$ & $\begin{array}{l}\text { Follow-Up Time } \\
\text { (Months) }\end{array}$ & $\begin{array}{l}\text { Clinical Status } \\
\text { before Treatment } \\
\text { or Control Group }\end{array}$ & $\begin{array}{l}\text { Clinical Status } \\
\text { after Treatment }\end{array}$ & Reference \\
\hline NCT01547091 & $\begin{array}{l}\text { Prospective } \\
\text { phase I/II }\end{array}$ & $\begin{array}{l}\text { Allogeneic UC } \\
\text { MSCs }\end{array}$ & 172 & $\begin{array}{c}4 \times 10^{7} \text { cells } / \text { patient, single IV } \\
\text { injection }\end{array}$ & 36 & $\begin{array}{c}\mathrm{DAS} 28 \uparrow, \mathrm{HAQ} \uparrow, \\
\mathrm{CRP} \uparrow, \mathrm{ESR} \uparrow, \mathrm{RF} \uparrow, \\
\text { anti-CCP } \uparrow, \\
\mathrm{TNF}-\alpha \uparrow, \mathrm{IL}-6 \uparrow\end{array}$ & $\begin{array}{c}\mathrm{DAS} 28 \downarrow, \mathrm{HAQ} \downarrow \\
\mathrm{CRP} \downarrow, \mathrm{ESR} \downarrow, \mathrm{RF} \downarrow, \\
\text { anti-CCP } \uparrow, \\
\text { TNF- } \alpha \downarrow, \mathrm{IL}-6 \downarrow\end{array}$ & {$[20,21]$} \\
\hline NCT02221258 & $\begin{array}{c}\text { Phase Ia, } \\
\text { open-label, } \\
\text { dose-escalation }\end{array}$ & $\begin{array}{l}\text { Allogeneic UCB } \\
\text { MSCs }\end{array}$ & 9 & $\begin{array}{c}2.5 \times 10^{7}, 5 \times 10^{7}, \text { or } 1 \times 10^{8} \\
\text { cells / patient, single IV injection }\end{array}$ & 1 & $\begin{array}{c}\mathrm{DAS} 28 \uparrow, \mathrm{VAS} \uparrow, \\
\mathrm{HAQ} \uparrow, \mathrm{CRP} \uparrow, \\
\mathrm{IL}-1 \beta \uparrow, \mathrm{IL}-6 \uparrow, \\
\mathrm{IL}-8 \uparrow, \mathrm{TNF}-\alpha \uparrow\end{array}$ & $\begin{array}{c}\text { DAS28 } \downarrow, \text { VAS } \downarrow \text {, } \\
\text { HAQ } \downarrow, \text { CRP } \downarrow \text {, } \\
\text { IL-1 } \beta \downarrow, \text { IL- } 6 \downarrow \text {, } \\
\text { IL- } 8 \downarrow, \text { TNF- } \alpha \downarrow\end{array}$ & [22] \\
\hline
\end{tabular}

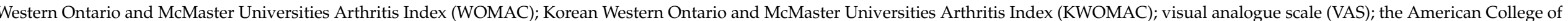

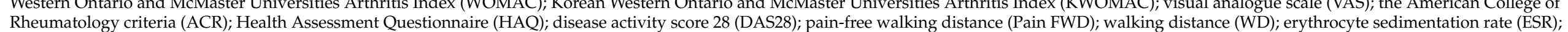
C-reactive protein (CRP); rheumatoid factor (RF); anti-cyclic citrullinated antibody (anti-CCP); non-significant (NS); increasing level ( $\uparrow$ ); decreasing level $(\downarrow)$. 
The first clinical study was started in 2010 by Ra and colleagues [17]. They investigated the safety and efficacy of IV and IA infusion of autologous AT MSCs in RA patients. The patients were split into three-dose regimens with different amounts of AT MSCs. The first group received two separate IV doses of $3 \times 10^{8}$ AT MSCs. The second group received two injections of AT MSCs: (1) intravenous (IV) injection of $2 \times 10^{8}$ and IA injection of $1 \times 10^{8}$ AT MSCs into finger, wrist, elbow and knee joints; (2) IV injection of $3.5 \times 10^{8}$ and IA injection of $1.5 \times 10^{8}$ AT MSCs. The third group received four IV injections of $2 \times 10^{8}$ AT MSCs in intervals of one month. The results of this study demonstrated that autologous AT MSCs are safe and provide clinical improvement in RA patients.

In another large randomized multicenter clinical trial, 53 patients with refractory RA were recruited for evaluation of efficacy of different dosages of allogeneic AT MSCs [16]. RA patients were divided into three groups and received IV injection of allogeneic AT MSCs with doses of 1,2 or $4 \times 10^{6}$ cells $/ \mathrm{kg}$ of body weight, three times with an interval of 1 week. The results of this study demonstrated that IV injection of allogeneic AT MSCs resulted in $2 \%$ clinical improvement in $20-45 \%$ of RA patients, according to the criteria of the ACR after 1 month regardless of the administered dose of MSCs. This therapeutic effect persisted after 3 months in 15-25\% of RA patients receiving MSCs, but not in the placebo control group. It was concluded that the use of MSCs was well tolerated without manifestation of dose-dependent toxicity.

From 2011 to 2013, 30 RA patients were recruited for a randomized, triple-blind placebo-controlled phase $1 / 2$ clinical trial to study the safety and tolerability of IA injection of autologous BM MSCs in RA patients [18]. The results published in 2018 showed that MSCs administration does not exert any adverse effects in RA patients. Moreover, it was revealed that in comparison to the patients in the placebo group, patients who received IA injection of BM MSCs demonstrated superior clinical results according to the Western Ontario and McMaster Universities Arthritis Index (WOMAC), visual analogue scale (VAS), time to jelling and pain-free walking distance up to 12 months. Based on these data, the authors have suggested that IA knee injection of BM MSCs is generally safe and well tolerated in RA patients.

Recently, Ghoryani and colleagues completed a successful clinical trial on the effects of IV administration of autologous BM MSCs on the various immunological, clinical and paraclinical indicators that are associated with the pathogenesis of RA in patients with refractory RA [19]. They showed that a single IV injection of $1 \times 10^{6} \mathrm{BM} \mathrm{MSCs} / \mathrm{kg}$ resulted in a significant decrease in Th17 cell number, disease activity score 28-erythrocyte sedimentation rate (DAS28-ESR) and VAS at 12 months after MSC therapy. However, no significant changes were observed in serum C-reactive protein (CRP) and anti-cyclic citrullinated antibody (anti-CCP) levels in refractory RA patients after injection of autologous BM MSCs. Taken together, these clinical data suggested that autologous BM MSCs can significantly ameliorate the severity and activity of refractory RA.

In 2013, a group of researchers performed a phase $1 / 2$ clinical trial to evaluate the safety and efficacy of IV injection of allogeneic hUC MSCs in patients with active RA [20]. In the study, 172 RA patients who failed to respond to conventional treatment were enrolled. The control group of patients received culture medium without UC MSCs. The experimental group of patients received a single dose of $4 \times 10^{7}$ UC MSCs. All groups of patients received DMARD treatment. The results of the clinical study showed that UC MSCs treatment did not induce any adverse effects and resulted in the following clinical improvements: a moderate reduction in inflammatory cytokines and chemokines, an increase in percentage of Tregs in peripheral blood and upregulation of IL-4-producing Th2 cells. In addition, a significant disease remission was observed by the ACR improvement criteria, the DAS28 score and the Health Assessment Questionnaire (HAQ), which were maintained for 3-6 months without repeated IV injection of UC MSCs. Moreover, an additional clinical study demonstrated that UC MSCs treatment can exert long-term beneficial effects in RA patients for up to 3 years [21]. Thus, this clinical trial showed that IV administration of allogeneic UC MSCs in combination with DMARDs was safe and effective in ameliorating 
disease activity in refractory RA patients, compared to the control group that received culture medium without UC MSCs.

In comparison to the aforementioned clinical studies, Korean scientists from KangStem Biotech performed a single IV infusion of $2.5 \times 10^{7}, 5 \times 10^{7}$ or $1 \times 10^{8}$ of allogeneic UCB MSCs to RA patients that did not previously receive any biologic drugs [22]. A phase Ia clinical trial showed that no patients exhibited any serious adverse events and abnormalities in hematologic profiles during and after the treatment. It was revealed that IV infusion of UCB MSCs $\left(1 \times 10^{8}\right.$ cells per patient) significantly reduced the levels of inflammatory cytokines in peripheral blood of RA patients at $24 \mathrm{~h}$, and the mean DAS28-ESR, HAQ and VAS score declined at week 4 . Despite some limitations, such as a relatively small number of recruited patients and the short duration of the follow-up period after UCB MSCs treatment, obtained clinical evidence demonstrated that a single high dose of allogeneic UCB MSCs was absolutely safe and effective for the treatment of refractory RA patients.

Thus, the early clinical studies described in this section indicate that both autologous and allogeneic MSC transplantation is safe and effective for treatment of refractory RA patients. No serious adverse effects have been reported in any of the RA patients during these clinical trials. The patients who received MSC treatment showed a moderate reduction in serum inflammatory markers, symptomatic improvement and significant disease remission. Moreover, it has been reported that the therapeutic effects after MSC treatment of RA patients can be maintained for up to 3 years with a stable clinical outcome, indicating the long-term safety and efficacy of MSC-based therapy.

Despite the promising results of clinical trials, there are some limitations in RA treatment with MSCs. Firstly, most studies have been conducted on RA patients enrolled from a single center, and sometimes without inclusion of a placebo control. In addition, patient enrollment in some clinical trials for evaluation of safety and efficacy was low. In some cases, MSC-treated groups included one or three patients. Therefore, to confirm the current clinical data on the efficacy of MSC therapy, a multiple-center, controlled trial should be conducted with the enrollment of a large number of RA patients. Secondly, currently there is not yet an optimal protocol for RA treatment with MSCs. This is due not only to the discrepancy of MSC sources, but also to the different routes of administration, treatment regimens and dosing used in the clinical studies. Taken together, these discrepancies in study designs have introduced difficulty when comparing therapeutic outcomes. Nevertheless, most clinical studies have revealed that regardless of the route of administration, the therapeutic efficacy of MSCs is achieved at a dosage of at least $1 \times 10^{6}$ cells $/ \mathrm{kg}$ of body weight after single or multiple injections. Although a dose-dependent relationship between MSC treatment and response has shown therapeutic effects, there is yet to be a well-defined and effective therapeutic window for RA with MSCs. Thus, treatment regimens and dosage adjustments must be studied thoroughly in future clinical studies. Thirdly, it is known that MSC therapy is an expensive treatment procedure compared to DMARDs or biologics. However, during prolonged drug therapy, $15-40 \%$ of RA patients develop resistance to these drugs and experience an increase in the incidence of side effects that adversely affect the patient's health. Completed clinical studies showed that infusion of MSCs is a safe and effective approach for treating RA patients and does not cause serious adverse effects. In this regard, MSCs may constitute a therapeutic vehicle for RA patients who are resistant to DMARDs. In addition, enhancement of immunomodulatory and anti-inflammatory properties of MSCs using the strategies of cell preconditioning may not improve therapeutic efficacy, but it may reduce the cost of manufacturing MSCs for an effective treatment for RA patients. Thus, future studies using the innovative cell technology can be the key to increasing scientific data on the therapeutic efficacy of MSC-based therapy.

\subsection{Strategies to Improve the Therapeutic Effects of MSCs}

As the therapeutic effects of MSCs have already been confirmed, researchers and clinicians are interested in the development of new strategies to increase the potential of MSCs in clinical applications for RA treatment [147]. To date, several strategies have been 
proposed to enhance the immunomodulatory and anti-inflammatory properties of MSCs in RA [14]. Among them are coculture methods, growth factors and cytokines, receptor agonists, hypoxia, autophagy and modifications in culture methods such as 3D culturing. An entirely different approach is the genetic modification of MSCs (Figure 2) [148-151]. Genes, which are involved in the increase in cell survival rate, immunomodulation and regeneration, are modulated by genetically engineered constructs, such as viral vectors or plasmids [152].

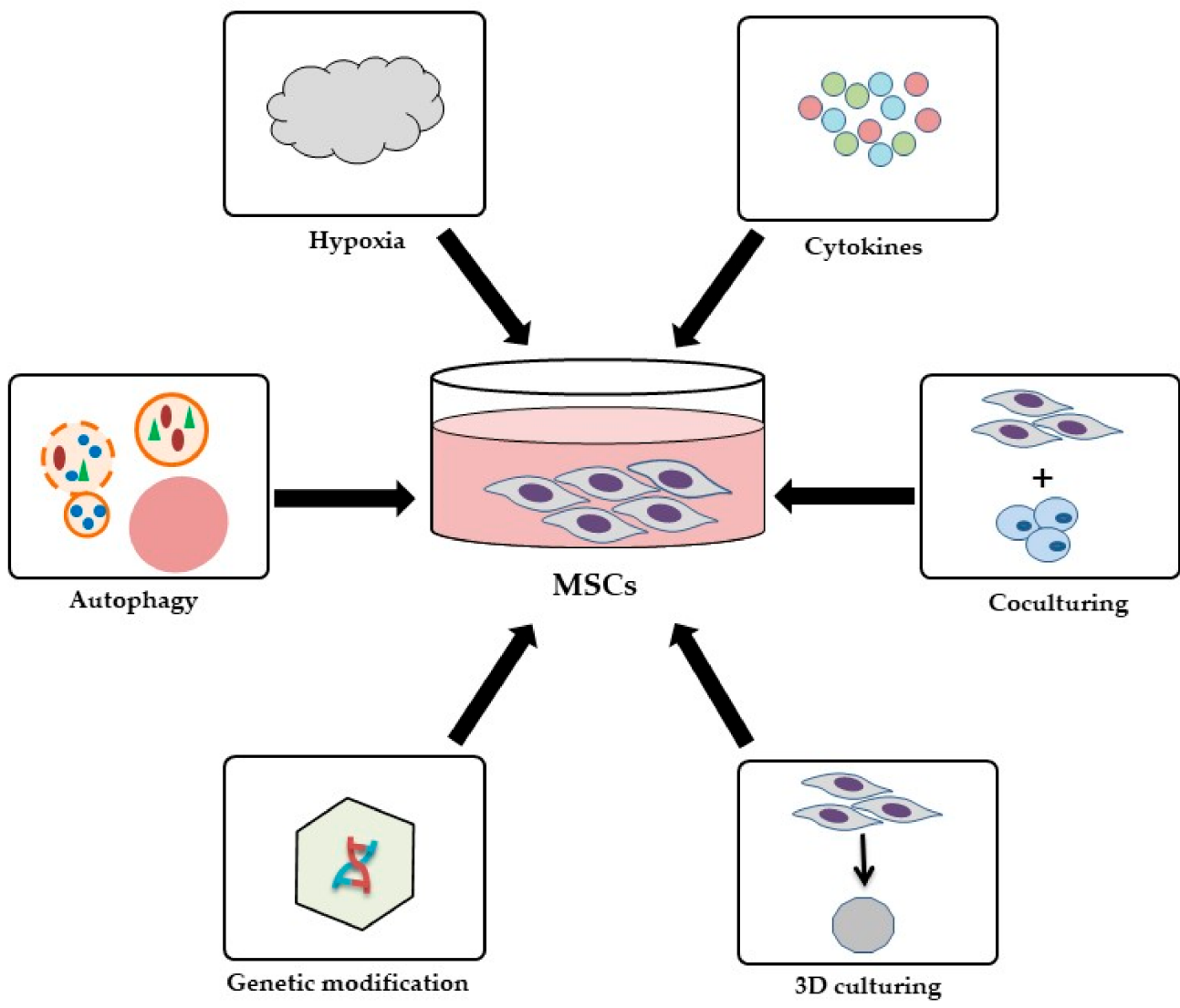

Figure 2. Different approaches to enhance immunomodulatory and anti-inflammatory properties of MSCs in RA.

In the strategy suggested by Lim and colleagues, the combined application of MSCs and IL-10-producing Tregs was more effective in suppressing inflammatory responses in joints and preventing the development of destructive arthritis in mice compared to the uncombined cell therapy [153]. Another promising strategy for the improvement of the therapeutic potential of MSCs is culturing the cells as 3D spheroids. Although MSC preconditioning in the form of 3D culturing has not yet been tested in an RA model, obtained data from several studies support the application of this strategy. 3D spheroid culture, in contrast to adherent monolayer culture, mimics a physiologically relevant microenvironment through intensive cell-cell and cell-matrix interactions. A number of studies have shown that culturing MSCs in a 3D microenvironment significantly increased their immunomodulatory and anti-inflammatory properties, apparently through upregulated TSG-6 and COX-2 expressed by MSC spheroids $[154,155]$. Furthermore, it was shown that both MSC spheroids and MSCs from spheroid more effectively suppress TNF- $\alpha$ production by LPS-stimulated peritoneal macrophages in vitro and inflammatory reactions in an in vivo mouse model of zymosan-induced peritonitis. In addition, it has been demonstrated that the 3D spheroid culture of MSCs produce higher levels of PGE2, TGF- $\beta 1$, IL-6 and IDO in contrast to a traditional 2D monolayer culture, confirming the activation of the immunomodulatory capacities of MSCs in a 3D environment [156]. 
Another strategy to improve the therapeutic effects of MSCs is to target the immune receptor agonists. TLRs expressed in MSCs have the ability to recognize potential threatening signals, and for this reason TLR3 and TLR4 have been relevant targets in implementing this strategy [157]. TLR3 and TLR4 proteins were targeted to improve cellular MSC properties by ligation of their agonists, polyinosinic:polycytidylic acid (poly I:C) and LPS, respectively. Once TLR3 is ligated, it generates further activation of downstream cascades. Poly(I:C) stimulates the Notch signaling pathway and enhances immunomodulatory properties, such as Treg promotion and impairment of Th1/Th17 cell expansion. In addition, TLR3 activation is shown to be involved with PGE2 expression that causes upregulation of an immunosuppression factor in BM MSCs [158,159]. Interesting data were reported by Moases and colleagues who demonstrated that caffeine primed MSCs can reduce the production level of pro-inflammatory cytokines, such as IFN- $\gamma$, IL- 6 and IL- $1 \beta$, in vitro and significantly downregulate the disease status in vivo compared to treatment with MSCs alone. Caffeine preconditioned MSCs caused a decrease in CRP, NO, myeloperoxidase and TNF- $\alpha$ levels in serum and conversely led to a significant increase in the levels of IL-10 than in the control group [160].

Additional prospective approaches to increase the immunomodulatory effects of MSCs for RA treatment are hypoxia and autophagy. Recent results confirm the prospective application of hypoxia and autophagy conditions for future MSC-based therapy for RA treatment. Some studies have shown that autophagy has an important role in protecting from ROS generated in MSCs after oxidative stress or irradiation [161]. For activation of autophagy in MSCs, pretreatment with starvation and mTOR inhibitor rapamycin are usually used. Hypoxic preconditioning increases the immunomodulatory effects of MSCs due to the upregulation of secreted immunoregulatory factors, including PGE2 and IDO [162-166]. Similarly, it has been shown that priming human MSCs with hypoxia or IFN- $\gamma$ resulted in immunosuppressive effects on CD4+ and CD8+ T cell proliferation. However, combined application of IFN- $\gamma$ and hypoxia synergistically inhibited $\mathrm{T}$ cell proliferation and significantly increased IDO and HLA-G expression. Treatment by one of the mentioned priming factors alone showed less of an effect, suggesting that the immunomodulatory effects of MSCs could be enhanced by the combinatory application of pro-inflammatory cytokines and hypoxia together [167].

Another promising strategy of MSC preconditioning is priming by pro-inflammatory cytokines. This approach is based on the fact that MSCs act as sensors of inflammation, and as a consequence, can significantly enhance their immunomodulatory and immunosuppressive properties [11]. In the presence of high levels of proinflammatory cytokines, MSCs are activated and acquire a pronounced immunosuppressive phenotype by producing high levels of anti-inflammatory mediators, such as PGE2, IDO, TGF- $\beta$, HGF, NO and heme oxygenase. Given this phenomenon, cell preconditioning with high concentrations of proinflammatory cytokines is used to enhance the immunosuppressive properties of MSCs. For example, some studies have demonstrated that when compared with untreated MSCs, MSCs preconditioned with IFN- $\gamma$ and/or IL-1 $\beta$ more effectively suppressed T cell proliferation, CD8+ T cell degranulation, NK cell and macrophage activation and the production of proinflammatory cytokines (TNF- $\alpha$, IFN- $\gamma$ and IL-2) by activated T cells [168-171]. On the other hand, treatment of MSCs with IFN- $\gamma$ led to an increase in the number of Tregs and the secretion of anti-inflammatory and immunoregulatory cytokines [172]. Sivanathan and colleagues showed that the preconditioning of human MSCs with IL-17A is as effective as treatment with IFN- $\gamma$ for suppressing the activation and proliferation of $\mathrm{T}$ cells and production of Th1 cytokines (TNF- $\alpha$, IFN- $\gamma$ and IL-2). In addition, IL-17A-treated MSCs significantly contributed to the generation of induced Tregs [173]. Preconditioning of MSCs with TNF- $\alpha$, IL- $1 \alpha$ or IL- $1 \beta$ as separate agents also enhances the immunomodulatory effects of MSCs. Furthermore, a number of studies have shown that the combined preconditioning of MSCs using IFN- $\gamma$ with one of the aforementioned proinflammatory cytokines can further enhance the immunosuppressive effects of MSCs [151]. 


\section{Conclusions}

MSCs have been extensively employed in treatment in experimental animal models for inflammatory and immune disorders. However, due to their robust abilities to exert immunomodulatory effects, they have been most therapeutically efficient in the treatment of autoimmune diseases, such as graft versus host disease, lupus erythematosus, multiple sclerosis and RA. The capacity of MSCs to reduce T cell proliferation and to suppress the inflammatory infiltrates and cytokines has been well documented. Additionally, it has been identified that modulatory mechanisms are mediated by multiple interactions, including cell-cell contacts and paracrine effects. Currently, MSC-based therapy is widely applied in clinical practice for the treatment of various diseases. According to the NIH, more than 350 clinical studies on MSC-based therapy are currently underway, and only about 10 of them are associated with RA treatment. In the context of RA, various immune cells, such as macrophages, DCs, NKs, B cells and T cells, with their numerous subtypes, are involved in inducing a complex immune response. Based on the complexity of disease pathogenesis, MSCs can be considered a promising alternative approach with the capacity to provide strong immunomodulatory properties for RA treatment. However, the environment, which is created by the cells of both innate and adaptive immunity and their secreted factors, influences the ability of MCSs to acquire either an anti- or pro-inflammatory phenotype, which can be reversed depending on the environment. Thus, prospective clinical application of MSCs in RA treatment needs to be further investigated. Moreover, it is important to note that the strategy of MSC priming, which is aimed to promote an anti-inflammatory phenotype, enhances the immunomodulatory potential for further therapeutic applications.

Author Contributions: M.S. conceptualized and wrote the original draft with support from A.I., S.A. and K.R.-M.; V.O. and A.S. conceptualized, reviewed and edited the manuscript. All authors have read and agreed to the published version of the manuscript.

Funding: This research was funded by the Ministry of Education and Science of the Republic of Kazakhstan (AP09259961).

Conflicts of Interest: The authors declare no conflict of interest.

\section{References}

1. Aletaha, D.; Smolen, J.S. Diagnosis and management of rheumatoid arthritis: A review. JAMA 2018, 320, 1360-1372. [CrossRef] [PubMed]

2. Myasoedova, E.; Davis, J.; Matteson, E.L.; Crowson, C.S. Is the epidemiology of rheumatoid arthritis changing? Results from a population-based incidence study, 1985-2014. Ann. Rheum. Dis. 2020, 79, 440-444. [CrossRef] [PubMed]

3. Firestein, G.S.; McInnes, I.B. Immunopathogenesis of Rheumatoid Arthritis. Immunity 2017, 46, 183-196. [CrossRef] [PubMed]

4. Smolen, J.S.; Aletaha, D.; Barton, A.; Burmester, G.R.; Emery, P.; Firestein, G.S.; Kavanaugh, A.; McInnes, I.B.; Solomon, D.H.; Strand, V.; et al. Rheumatoid arthritis. Nat. Rev. Dis. Primers 2018, 4, 18001. [CrossRef] [PubMed]

5. Guo, Q.; Wang, Y.; Xu, D.; Nossent, J.; Pavlos, N.J.; Xu, J. Rheumatoid arthritis: Pathological mechanisms and modern pharmacologic therapies. Bone Res. 2018, 6, 1-14. [CrossRef]

6. Lin, Y.-J.; Anzaghe, M.; Schülke, S. Update on the pathomechanism, diagnosis, and treatment options for rheumatoid arthritis. Cells 2020, 9, 880. [CrossRef]

7. Altawil, R.; Saevarsdottir, S.; Wedrén, S.; Alfredsson, L.; Klareskog, L.; Lampa, J. Remaining Pain in Early Rheumatoid Arthritis Patients Treated With Methotrexate. Arthritis Care Res. 2016, 68, 1061-1068. [CrossRef]

8. Singh, J.A.; Saag, K.G.; Bridges, S.L., Jr.; Akl, E.A.; Bannuru, R.R.; Sullivan, M.C.; Vaysbrot, E.; McNaughton, C.; Osani, M.; Shmerling, R.H.; et al. 2015 American College of Rheumatology Guideline for the Treatment of Rheumatoid Arthritis. Arthritis Rheumatol. 2016, 68, 1-26. [CrossRef]

9. Lopez-Santalla, M.; Bueren, J.A.; Garin, M.I. Mesenchymal stem/stromal cell-based therapy for the treatment of rheumatoid arthritis: An update on preclinical studies. EBioMedicine 2021, 69, 103427. [CrossRef]

10. Ansboro, S.; Roelofs, A.J.; De Bari, C. Mesenchymal stem cells for the management of rheumatoid arthritis: Immune modulation, repair or both? Curr. Opin. Rheumatol. 2017, 29, 201-207. [CrossRef]

11. Bernardo, M.E.; Fibbe, W.E. Mesenchymal stromal cells: Sensors and switchers of inflammation. Cell Stem Cell 2013, 13, $392-402$. [CrossRef]

12. Liu, H.; Li, R.; Liu, T.; Yang, L.; Yin, G.; Xie, Q. Immunomodulatory Effects of Mesenchymal Stem Cells and Mesenchymal Stem Cell-Derived Extracellular Vesicles in Rheumatoid Arthritis. Front. Immunol. 2020, 11, 1912. [CrossRef] 
13. Uccelli, A.; de Rosbo, N.K. The immunomodulatory function of mesenchymal stem cells: Mode of action and pathways. Ann. N. Y. Acad. Sci. 2015, 1351, 114-126. [CrossRef]

14. Lee, B.-C.; Kang, K.-S. Functional enhancement strategies for immunomodulation of mesenchymal stem cells and their therapeutic application. Stem Cell Res. Ther. 2020, 11,1-10. [CrossRef]

15. Liu, L.; Wong, C.W.; Han, M.; Farhoodi, H.P.; Liu, G.; Liu, Y.; Liao, W.; Zhao, W. Meta-analysis of preclinical studies of mesenchymal stromal cells to treat rheumatoid arthritis. EBioMedicine 2019, 47, 563-577. [CrossRef]

16. Álvaro-Gracia, J.M.; Jover, J.A.; García-Vicuña, R.; Carreño, L.; Alonso, A.; Marsal, S.; Blanco, F.; Martínez-Taboada, V.M.; Taylor, P.; Martín-Martín, C. Intravenous administration of expanded allogeneic adipose-derived mesenchymal stem cells in refractory rheumatoid arthritis (Cx611): Results of a multicentre, dose escalation, randomised, single-blind, placebo-controlled phase Ib/IIa clinical trial. Ann. Rheum. Dis. 2017, 76, 196-202. [CrossRef]

17. Ra, J.C.; Shin, I.S.; Kim, S.H.; Kang, S.K.; Kang, B.C.; Lee, H.Y.; Kim, Y.J.; Jo, J.Y.; Yoon, E.J.; Choi, H.J. Safety of intravenous infusion of human adipose tissue-derived mesenchymal stem cells in animals and humans. Stem Cells Dev. 2011, 20, 1297-1308. [CrossRef]

18. Shadmanfar, S.; Labibzadeh, N.; Emadedin, M.; Jaroughi, N.; Azimian, V.; Mardpour, S.; Kakroodi, F.A.; Bolurieh, T.; Hosseini, S.E.; Chehrazi, M. Intra-articular knee implantation of autologous bone marrow-derived mesenchymal stromal cells in rheumatoid arthritis patients with knee involvement: Results of a randomized, triple-blind, placebo-controlled phase $1 / 2$ clinical trial. Cytotherapy 2018, 20, 499-506. [CrossRef]

19. Ghoryani, M.; Shariati-Sarabi, Z.; Tavakkol-Afshari, J.; Ghasemi, A.; Poursamimi, J.; Mohammadi, M. Amelioration of clinical symptoms of patients with refractory rheumatoid arthritis following treatment with autologous bone marrow-derived mesenchymal stem cells: A successful clinical trial in Iran. Biomed. Pharmacother. 2019, 109, 1834-1840. [CrossRef]

20. Wang, L.; Wang, L.; Cong, X.; Liu, G.; Zhou, J.; Bai, B.; Li, Y.; Bai, W.; Li, M.; Ji, H. Human umbilical cord mesenchymal stem cell therapy for patients with active rheumatoid arthritis: Safety and efficacy. Stem Cells Dev. 2013, 22, 3192-3202. [CrossRef]

21. Wang, L.; Huang, S.; Li, S.; Li, M.; Shi, J.; Bai, W.; Wang, Q.; Zheng, L.; Liu, Y. Efficacy and safety of umbilical cord mesenchymal stem cell therapy for rheumatoid arthritis patients: A prospective phase I/II study. Drug Des. Dev. Ther. 2019, 13, 4331. [CrossRef]

22. Park, E.H.; Lim, H.s.; Lee, S.; Roh, K.; Seo, K.W.; Kang, K.S.; Shin, K. Intravenous Infusion of Umbilical Cord Blood Derived Mesenchymal Stem Cells in Rheumatoid Arthritis: A Phase Ia Clinical Trial. Stem Cells Transl. Med. 2018, 7, 636-642. [CrossRef]

23. Chatzidionysiou, K.; Emamikia, S.; Nam, J.; Ramiro, S.; Smolen, J.; van der Heijde, D.; Dougados, M.; Bijlsma, J.; Burmester, G.; Scholte, M. Efficacy of glucocorticoids, conventional and targeted synthetic disease-modifying antirheumatic drugs: A systematic literature review informing the 2016 update of the EULAR recommendations for the management of rheumatoid arthritis. Ann. Rheum. Dis. 2017, 76, 1102-1107. [CrossRef]

24. Papadopoli, D.J.; Ma, E.H.; Roy, D.; Russo, M.; Bridon, G.; Avizonis, D.; Jones, R.G.; St-Pierre, J. Methotrexate elicits pro-respiratory and anti-growth effects by promoting AMPK signaling. Sci. Rep. 2020, 10, 7838. [CrossRef]

25. Cronstein, B.N.; Aune, T.M. Methotrexate and its mechanisms of action in inflammatory arthritis. Nat. Rev. Rheumatol. 2020, 16, 145-154. [CrossRef]

26. Paul, M.; Hemshekhar, M.; Thushara, R.M.; Sundaram, M.S.; NaveenKumar, S.K.; Naveen, S.; Devaraja, S.; Somyajit, K.; West, R.; Nayaka, S.C. Methotrexate promotes platelet apoptosis via JNK-mediated mitochondrial damage: Alleviation by N-acetylcysteine and N-acetylcysteine amide. PLoS ONE 2015, 10, e0127558. [CrossRef]

27. Solomon, D.H.; Glynn, R.J.; Karlson, E.W.; Lu, F.; Corrigan, C.; Colls, J.; Xu, C.; MacFadyen, J.; Barbhaiya, M.; Berliner, N.; et al. Adverse Effects of Low-Dose Methotrexate: A Randomized Trial. Ann. Intern. Med. 2020, 172, 369-380. [CrossRef]

28. Brown, P.M.; Pratt, A.G.; Isaacs, J.D. Mechanism of action of methotrexate in rheumatoid arthritis, and the search for biomarkers. Nat. Rev. Rheumatol. 2016, 12, 731-742. [CrossRef]

29. Tian, H.; Cronstein, B.N. Understanding the mechanisms of action of methotrexate. Bull. NYU Hosp. Jt. Dis. 2007, 65, 168-173.

30. Van Ede, A.E.; Laan, R.F.; Rood, M.J.; Huizinga, T.W.; Van De Laar, M.A.; Denderen, C.J.V.; Westgeest, T.A.; Romme, T.C.; De Rooij, D.J.R.; Jacobs, M.J. Effect of folic or folinic acid supplementation on the toxicity and efficacy of methotrexate in rheumatoid arthritis: A forty-eight-week, multicenter, randomized, double-blind, placebo-controlled study. Arthritis Rheum. Off. J. Am. Coll. Rheumatol. 2001, 44, 1515-1524. [CrossRef]

31. Sparks, J.A. Rheumatoid Arthritis. Ann. Intern. Med. 2019, 170, ITC1-ITC16. [CrossRef] [PubMed]

32. Smolen, J.S.; Landewé, R.B.M.; Bijlsma, J.W.J.; Burmester, G.R.; Dougados, M.; Kerschbaumer, A.; McInnes, I.B.; Sepriano, A.; van Vollenhoven, R.F.; de Wit, M.; et al. EULAR recommendations for the management of rheumatoid arthritis with synthetic and biological disease-modifying antirheumatic drugs: 2019 update. Ann. Rheum. Dis. 2020, 79, 685-699. [CrossRef] [PubMed]

33. Scott, D.L.; Wolfe, F.; Huizinga, T.W. Rheumatoid arthritis. Lancet 2010, 376, 1094-1108. [CrossRef]

34. Ho, C.T.K.; Mok, C.C.; Cheung, T.T.; Kwok, K.Y.; Yip, R.M.L. Management of rheumatoid arthritis: 2019 updated consensus recommendations from the Hong Kong Society of Rheumatology. Clin. Rheumatol. 2019, 38, 3331-3350. [CrossRef]

35. Daien, C.I.; Charlotte, H.; Combe, B.; Landewe, R. Non-pharmacological and pharmacological interventions in patients with early arthritis: A systematic literature review informing the 2016 update of EULAR recommendations for the management of early arthritis. RMD Open 2017, 3, e000404. [CrossRef]

36. Smolen, J.S.; Landewé, R.; Bijlsma, J.; Burmester, G.; Chatzidionysiou, K.; Dougados, M.; Nam, J.; Ramiro, S.; Voshaar, M.; van Vollenhoven, R.; et al. EULAR recommendations for the management of rheumatoid arthritis with synthetic and biological disease-modifying antirheumatic drugs: 2016 update. Ann. Rheum. Dis. 2017, 76, 960-977. [CrossRef] 
37. Surjit, M.; Ganti, K.P.; Mukherji, A.; Ye, T.; Hua, G.; Metzger, D.; Li, M.; Chambon, P. Widespread negative response elements mediate direct repression by agonist-liganded glucocorticoid receptor. Cell 2011, 145, 224-241. [CrossRef]

38. Coutinho, A.E.; Chapman, K.E. The anti-inflammatory and immunosuppressive effects of glucocorticoids, recent developments and mechanistic insights. Mol. Cell. Endocrinol. 2011, 335, 2-13. [CrossRef]

39. Ronchetti, S.; Migliorati, G.; Bruscoli, S.; Riccardi, C. Defining the role of glucocorticoids in inflammation. Clin. Sci. 2018, 132, 1529-1543. [CrossRef]

40. Liu, D.; Ahmet, A.; Ward, L.; Krishnamoorthy, P.; Mandelcorn, E.D.; Leigh, R.; Brown, J.P.; Cohen, A.; Kim, H. A practical guide to the monitoring and management of the complications of systemic corticosteroid therapy. Allergy Asthma Clin. Immunol. 2013, 9 , 1-25. [CrossRef]

41. Yasir, M.; Goyal, A.; Bansal, P.; Sonthalia, S. Corticosteroid Adverse Effects. In StatPearls; StatPearls Publishing LLC.: Treasure Island, FL, USA, 2021.

42. Combe, B.; Landewe, R.; Daien, C.I.; Hua, C.; Aletaha, D.; Álvaro-Gracia, J.M.; Bakkers, M.; Brodin, N.; Burmester, G.R.; Codreanu, C. 2016 update of the EULAR recommendations for the management of early arthritis. Ann. Rheum. Dis. 2017, 76, 948-959. [CrossRef]

43. van der Heide, A.; Jacobs, J.W.; Bijlsma, J.W.; Heurkens, A.H.; van Booma-Frankfort, C.; van der Veen, M.J.; Haanen, H.C.; Hofman, D.M.; van Albada-Kuipers, G.A.; ter Borg, E.J.; et al. The effectiveness of early treatment with "second-line" antirheumatic drugs. A randomized, controlled trial. Ann. Intern. Med. 1996, 124, 699-707. [CrossRef]

44. Lis, K.; Kuzawińska, O.; Bałkowiec-Iskra, E. Tumor necrosis factor inhibitors-state of knowledge. Arch. Med. Sci. AMS 2014, 10, 1175. [CrossRef]

45. Perpétuo, I.P.; Caetano-Lopes, J.; Rodrigues, A.M.; Campanilho-Marques, R.; Ponte, C.; Canhão, H.; Ainola, M.; Fonseca, J.E. Effect of tumor necrosis factor inhibitor therapy on osteoclasts precursors in rheumatoid arthritis. BioMed Res. Int. 2017, $2017,2690402$. [CrossRef]

46. Rein, P.; Mueller, R.B. Treatment with biologicals in rheumatoid arthritis: An overview. Rheumatol. Ther. 2017, 4, 247-261. [CrossRef]

47. den Broeder, A.A.; van Herwaarden, N.; van den Bemt, B.J. Therapeutic drug monitoring of biologicals in rheumatoid arthritis: A disconnect between beliefs and facts. Curr. Opin. Rheumatol. 2018, 30, 266-275. [CrossRef]

48. Rotondo, J.C.; Bononi, I.; Puozzo, A.; Govoni, M.; Foschi, V.; Lanza, G.; Gafà, R.; Gaboriaud, P.; Touzé, F.A.; Selvatici, R.; et al. Merkel Cell Carcinomas Arising in Autoimmune Disease Affected Patients Treated with Biologic Drugs, Including Anti-TNF. Clin. Cancer Res. 2017, 23, 3929-3934. [CrossRef]

49. Andersson, K.M.; Cavallini, N.F.; Hu, D.; Brisslert, M.; Cialic, R.; Valadi, H.; Erlandsson, M.C.; Silfverswärd, S.; Pullerits, R.; Kuchroo, V.K. Pathogenic transdifferentiation of Th17 cells contribute to perpetuation of rheumatoid arthritis during anti-TNF treatment. Mol. Med. 2015, 21, 536-543. [CrossRef]

50. Romas, E.; Sims, N.A.; Hards, D.K.; Lindsay, M.; Quinn, J.W.; Ryan, P.F.; Dunstan, C.R.; Martin, T.J.; Gillespie, M.T. Osteoprotegerin reduces osteoclast numbers and prevents bone erosion in collagen-induced arthritis. Am. J. Pathol. 2002, 161, 1419-1427. [CrossRef]

51. Mann, D.L. Innate immunity and the failing heart: The cytokine hypothesis revisited. Circ. Res. 2015, 116, 1254-1268. [CrossRef]

52. Mok, C.C. Rituximab for the treatment of rheumatoid arthritis: An update. Drug Des. Dev. Ther. 2014, 8, 87. [CrossRef] [PubMed]

53. Langdon, K.; Haleagrahara, N. Regulatory T-cell dynamics with abatacept treatment in rheumatoid arthritis. Int. Rev. Immunol. 2018, 37, 206-214. [CrossRef] [PubMed]

54. Fukuyo, S.; Nakayamada, S.; Iwata, S.; Kubo, S.; Saito, K.; Tanaka, Y. Abatacept therapy reduces CD28+ CXCR5+ follicular helper-like T cells in patients with rheumatoid arthritis. Clin. Exp. Rheumatol. 2017, 35, 562-570. [PubMed]

55. Kishimoto, T.; Kang, S.; Tanaka, T. IL-6: A new era for the treatment of autoimmune inflammatory diseases. Innov. Med. 2015, 26, 131-147.

56. Genovese, M.C.; Durez, P.; Richards, H.B.; Supronik, J.; Dokoupilova, E.; Mazurov, V.; Aelion, J.A.; Lee, S.-H.; Codding, C.E.; Kellner, H. Efficacy and safety of secukinumab in patients with rheumatoid arthritis: A phase II, dose-finding, double-blind, randomised, placebo controlled study. Ann. Rheum. Dis. 2013, 72, 863-869. [CrossRef]

57. Martin, D.A.; Churchill, M.; Flores-Suarez, L.F.; Cardiel, M.H.; Wallace, D.; Martin, R.; Phillips, K.; Kaine, J.L.; Dong, H.; Salinger, $\mathrm{D}$. A phase Ib multiple ascending dose study evaluating safety, pharmacokinetics, and early clinical response of brodalumab, a human anti-IL-17R antibody, in methotrexate-resistant rheumatoid arthritis. Arthritis Res. Ther. 2013, 15, 1-9. [CrossRef]

58. Nam, J.L.; Takase-Minegishi, K.; Ramiro, S.; Chatzidionysiou, K.; Smolen, J.S.; van der Heijde, D.; Bijlsma, J.W.; Burmester, G.R.; Dougados, M.; Scholte-Voshaar, M.; et al. Efficacy of biological disease-modifying antirheumatic drugs: A systematic literature review informing the 2016 update of the EULAR recommendations for the management of rheumatoid arthritis. Ann. Rheum. Dis. 2017, 76, 1113-1136. [CrossRef]

59. Jamilloux, Y.; El Jammal, T.; Vuitton, L.; Gerfaud-Valentin, M.; Kerever, S.; Sève, P. JAK inhibitors for the treatment of autoimmune and inflammatory diseases. Autoimmun. Rev. 2019, 18, 102390. [CrossRef]

60. Verschueren, P.; De Cock, D.; Corluy, L.; Joos, R.; Langenaken, C.; Taelman, V.; Raeman, F.; Ravelingien, I.; Vandevyvere, K.; Lenaerts, J. Methotrexate in combination with other DMARDs is not superior to methotrexate alone for remission induction with moderate-to-high-dose glucocorticoid bridging in early rheumatoid arthritis after 16 weeks of treatment: The CareRA trial. Ann. Rheum. Dis. 2015, 74, 27-34. [CrossRef]

61. Yoshida, Y.; Tanaka, T. Interleukin 6 and rheumatoid arthritis. BioMed Res. Int. 2014, 2014, 1-12. [CrossRef] 
62. Gertel, S.; Mahagna, H.; Karmon, G.; Watad, A.; Amital, H. Tofacitinib attenuates arthritis manifestations and reduces the pathogenic CD4 T cells in adjuvant arthritis rats. Clin. Immunol. 2017, 184, 77-81. [CrossRef]

63. Cheung, T.T.; McInnes, I.B. Future therapeutic targets in rheumatoid arthritis? In Seminars in Immunopathology; Springer: Berlin/Heidelberg, Germany, 2017.

64. Taylor, P.C.; Keystone, E.C.; Van Der Heijde, D.; Weinblatt, M.E.; del Carmen Morales, L.; Reyes Gonzaga, J.; Yakushin, S.; Ishii, T.; Emoto, K.; Beattie, S. Baricitinib versus placebo or adalimumab in rheumatoid arthritis. N. Engl. J. Med. 2017, 376, 652-662. [CrossRef]

65. Burmester, G.R.; Kremer, J.M.; Van den Bosch, F.; Kivitz, A.; Bessette, L.; Li, Y.; Zhou, Y.; Othman, A.A.; Pangan, A.L.; Camp, H.S. Safety and efficacy of upadacitinib in patients with rheumatoid arthritis and inadequate response to conventional synthetic disease-modifying anti-rheumatic drugs (SELECT-NEXT): A randomised, double-blind, placebo-controlled phase 3 trial. Lancet 2018, 391, 2503-2512. [CrossRef]

66. Kremer, J.; Li, Z.G.; Hall, S.; Fleischmann, R.; Genovese, M.; Martin-Mola, E.; Isaacs, J.D.; Gruben, D.; Wallenstein, G.; Krishnaswami, S.; et al. Tofacitinib in combination with nonbiologic disease-modifying antirheumatic drugs in patients with active rheumatoid arthritis: A randomized trial. Ann. Intern. Med. 2013, 159, 253-261. [CrossRef]

67. Crofford, L.J. Use of NSAIDs in treating patients with arthritis. Arthritis Res. Ther. 2013, 15, 1-10. [CrossRef]

68. Chen, Y.F.; Jobanputra, P.; Barton, P.; Bryan, S.; Fry-Smith, A.; Harris, G.; Taylor, R.S. Cyclooxygenase-2 selective non-steroidal anti-inflammatory drugs (etodolac, meloxicam, celecoxib, rofecoxib, etoricoxib, valdecoxib and lumiracoxib) for osteoarthritis and rheumatoid arthritis: A systematic review and economic evaluation. Health Technol. Assess. 2008, 12, 1-278. [CrossRef]

69. Knut, L. Radiosynovectomy in the therapeutic management of arthritis. World J. Nucl. Med. 2015, 14, 10. [CrossRef]

70. Pajarinen, J.; Lin, T.-H.; Sato, T.; Yao, Z.; Goodman, S. Interaction of materials and biology in total joint replacement-successes, challenges and future directions. J. Mater. Chem. B 2014, 2, 7094-7108. [CrossRef]

71. Tayar, J.H.; Suarez-Almazor, M.E. New understanding and approaches to treatment in rheumatoid arthritis. Br. Med Bull. 2010, 94, 201-214. [CrossRef]

72. Shewaiter, M.A.; Hammady, T.M.; El-Gindy, A.; Hammadi, S.H.; Gad, S. Formulation and characterization of leflunomide/diclofenac sodium microemulsion base-gel for the transdermal treatment of inflammatory joint diseases. J. Drug Deliv. Sci. Technol. 2021, 61, 102110. [CrossRef]

73. Choi, J.; Fenando, A. Sulfasalazine. In StatPearls; StatPearls Publishing LLC.: Treasure Island, FL, USA, 2021.

74. Stein, M.; Bell, M.J.; Ang, L.-C. Hydroxychloroquine neuromyotoxicity. J. Rheumatol. 2000, 27, $2927-2931$.

75. Pers, Y.-M.; Padern, G. Revisiting the cardiovascular risk of hydroxychloroquine in RA. Nat. Rev. Rheumatol. 2020, 16, 671-672. [CrossRef]

76. Ma, X.; Xu, S. TNF inhibitor therapy for rheumatoid arthritis. Biomed. Rep. 2013, 1, 177-184. [CrossRef]

77. Ramírez, J.; Cañete, J.D. Anakinra for the treatment of rheumatoid arthritis: A safety evaluation. Expert Opin. Drug Saf. 2018, 17, 727-732. [CrossRef]

78. Cohen, M.D.; Keystone, E. Rituximab for rheumatoid arthritis. Rheumatol. Ther. 2015, 2, 99-111. [CrossRef]

79. Blair, H.A.; Deeks, E.D. Abatacept: A Review in Rheumatoid Arthritis. Drugs 2017, 77, 1221-1233. [CrossRef]

80. Scott, L.J. Tocilizumab: A Review in Rheumatoid Arthritis. Drugs 2017, 77, 1865-1879. [CrossRef]

81. Koenders, M.I.; van den Berg, W.B. Secukinumab for rheumatology: Development and its potential place in therapy. Drug Des. Devel. Ther. 2016, 10, 2069-2080. [CrossRef]

82. Golbari, N.M.; Basehore, B.M.; Zito, P.M. Brodalumab. In StatPearls; @ 2021 ; StatPearls Publishing LLC.: Treasure Island, FL, USA, 2021.

83. Dhillon, S. Tofacitinib: A Review in Rheumatoid Arthritis. Drugs 2017, 77, 1987-2001. [CrossRef]

84. Al-Salama, Z.T.; Scott, L.J. Baricitinib: A Review in Rheumatoid Arthritis. Drugs 2018, 78, 761-772. [CrossRef]

85. Tanaka, Y. A review of upadacitinib in rheumatoid arthritis. Mod. Rheumatol. 2020, 30, 779-787. [CrossRef] [PubMed]

86. Oray, M.; Abu Samra, K.; Ebrahimiadib, N.; Meese, H.; Foster, C.S. Long-term side effects of glucocorticoids. Expert Opin. Drug Saf. 2016, 15, 457-465. [CrossRef] [PubMed]

87. Marinescu, C.I.; Preda, M.B.; Burlacu, A. A procedure for in vitro evaluation of the immunosuppressive effect of mouse mesenchymal stem cells on activated T cell proliferation. Stem. Cell Res. Ther. 2021, 12, 319. [CrossRef] [PubMed]

88. Mushahary, D.; Spittler, A.; Kasper, C.; Weber, V.; Charwat, V. Isolation, cultivation, and characterization of human mesenchymal stem cells. Cytom. Part A 2018, 93, 19-31. [CrossRef]

89. Dominici, M.; Le Blanc, K.; Mueller, I.; Slaper-Cortenbach, I.; Marini, F.; Krause, D.; Deans, R.; Keating, A.; Prockop, D.; Horwitz, E. Minimal criteria for defining multipotent mesenchymal stromal cells. The International Society for Cellular Therapy position statement. Cytotherapy 2006, 8, 315-317. [CrossRef]

90. Li, T.; Xia, M.; Gao, Y.; Chen, Y.; Xu, Y. Human umbilical cord mesenchymal stem cells: An overview of their potential in cell-based therapy. Expert Opin. Biol. Ther. 2015, 15, 1293-1306. [CrossRef]

91. Heo, J.S.; Choi, Y.; Kim, H.S.; Kim, H.O. Comparison of molecular profiles of human mesenchymal stem cells derived from bone marrow, umbilical cord blood, placenta and adipose tissue. Int. J. Mol. Med. 2016, 37, 115-125. [CrossRef]

92. Sun, Q.; Nakata, H.; Yamamoto, M.; Kasugai, S.; Kuroda, S. Comparison of gingiva-derived and bone marrow mesenchymal stem cells for osteogenesis. J. Cell. Mol. Med. 2019, 23, 7592-7601. [CrossRef] 
93. Zupan, J. Human Synovium-Derived Mesenchymal Stem Cells: Ex Vivo Analysis. Methods Mol. Biol. 2019, $2045,145-154$. [CrossRef]

94. De Bari, C.; Dell'Accio, F.; Vanlauwe, J.; Eyckmans, J.; Khan, I.M.; Archer, C.W.; Jones, E.A.; McGonagle, D.; Mitsiadis, T.A.; Pitzalis, C. Mesenchymal multipotency of adult human periosteal cells demonstrated by single-cell lineage analysis. Arthritis Rheum. 2006, 54, 1209-1221. [CrossRef]

95. Gaur, M.; Dobke, M.; Lunyak, V.V. Mesenchymal Stem Cells from Adipose Tissue in Clinical Applications for Dermatological Indications and Skin Aging. Int. J. Mol. Sci. 2017, 18, 208. [CrossRef]

96. Gan, L.; Liu, Y.; Cui, D.; Pan, Y.; Zheng, L.; Wan, M. Dental Tissue-Derived Human Mesenchymal Stem Cells and Their Potential in Therapeutic Application. Stem Cells Int. 2020, 2020, 8864572. [CrossRef]

97. Bieback, K.; Netsch, P. Isolation, culture, and characterization of human umbilical cord blood-derived mesenchymal stromal cells. In Mesenchymal Stem Cells; Springer: Berlin/Heidelberg, Germany, 2016; pp. 245-258.

98. Lanzillotti, C.; De Mattei, M.; Mazziotta, C.; Taraballi, F.; Rotondo, J.C.; Tognon, M.; Martini, F. Long Non-coding RNAs and MicroRNAs Interplay in Osteogenic Differentiation of Mesenchymal Stem Cells. Front. Cell Dev. Biol. 2021, 9, 646032. [CrossRef]

99. Luz-Crawford, P.; Djouad, F.; Toupet, K.; Bony, C.; Franquesa, M.; Hoogduijn, M.J.; Jorgensen, C.; Noël, D. Mesenchymal stem cell-derived Interleukin 1 receptor antagonist promotes macrophage polarization and inhibits B cell differentiation. Stem. Cells 2016, 34, 483-492. [CrossRef]

100. Luz-Crawford, P.; Kurte, M.; Bravo-Alegría, J.; Contreras, R.; Nova-Lamperti, E.; Tejedor, G.; Noël, D.; Jorgensen, C.; Figueroa, F.; Djouad, F. Mesenchymal stem cells generate a CD4+ CD25+ Foxp3+ regulatory T cell population during the differentiation process of Th1 and Th17 cells. Stem Cell Res. Ther. 2013, 4, 1-12. [CrossRef]

101. Luque-Campos, N.; Contreras-López, R.A.; Jose Paredes-Martínez, M.; Torres, M.J.; Bahraoui, S.; Wei, M.; Espinoza, F.; Djouad, F.; Elizondo-Vega, R.J.; Luz-Crawford, P. Mesenchymal stem cells improve rheumatoid arthritis progression by controlling memory T cell response. Front. Immunol. 2019, 10, 798. [CrossRef]

102. Fan, X.L.; Zhang, Y.; Li, X.; Fu, Q.L. Mechanisms underlying the protective effects of mesenchymal stem cell-based therapy. Cell. Mol. Life Sci. 2020, 77, 2771-2794. [CrossRef]

103. Yang, Y.; He, X.; Zhao, R.; Guo, W.; Zhu, M.; Xing, W.; Jiang, D.; Liu, C.; Xu, X. Serum IFN- $\gamma$ levels predict the therapeutic effect of mesenchymal stem cell transplantation in active rheumatoid arthritis. J. Transl. Med. 2018, 16, 1-9. [CrossRef]

104. Hong, J.; Hueckelhoven, A.; Wang, L.; Schmitt, A.; Wuchter, P.; Tabarkiewicz, J.; Kleist, C.; Bieback, K.; Ho, A.D.; Schmitt, M. Indoleamine 2,3-dioxygenase mediates inhibition of virus-specific CD8(+) T cell proliferation by human mesenchymal stromal cells. Cytotherapy 2016, 18, 621-629. [CrossRef]

105. Ling, W.; Zhang, J.; Yuan, Z.; Ren, G.; Zhang, L.; Chen, X.; Rabson, A.B.; Roberts, A.I.; Wang, Y.; Shi, Y. Mesenchymal stem cells use IDO to regulate immunity in tumor microenvironment. Cancer Res. 2014, 74, 1576-1587. [CrossRef]

106. Spaggiari, G.M.; Capobianco, A.; Abdelrazik, H.; Becchetti, F.; Mingari, M.C.; Moretta, L. Mesenchymal stem cells inhibit natural killer-cell proliferation, cytotoxicity, and cytokine production: Role of indoleamine 2,3-dioxygenase and prostaglandin E2. Blood 2008, 111, 1327-1333. [CrossRef]

107. Vizoso, F.J.; Eiro, N.; Cid, S.; Schneider, J.; Perez-Fernandez, R. Mesenchymal Stem Cell Secretome: Toward Cell-Free Therapeutic Strategies in Regenerative Medicine. Int. J. Mol. Sci. 2017, 18, 1852. [CrossRef]

108. Maffioli, E.; Nonnis, S.; Angioni, R.; Santagata, F.; Calì, B.; Zanotti, L.; Negri, A.; Viola, A.; Tedeschi, G. Proteomic analysis of the secretome of human bone marrow-derived mesenchymal stem cells primed by pro-inflammatory cytokines. J. Proteom. 2017, 166, 115-126. [CrossRef]

109. Shin, T.H.; Lee, B.C.; Choi, S.W.; Shin, J.H.; Kang, I.; Lee, J.Y.; Kim, J.J.; Lee, H.K.; Jung, J.E.; Choi, Y.W.; et al. Human adipose tissue-derived mesenchymal stem cells alleviate atopic dermatitis via regulation of B lymphocyte maturation. Oncotarget 2017, 8, 512-522. [CrossRef]

110. Kalinski, P. Regulation of immune responses by prostaglandin E2. J. Immunol. 2012, 188, 21-28. [CrossRef]

111. Wang, G.; Cao, K.; Liu, K.; Xue, Y.; Roberts, A.I.; Li, F.; Han, Y.; Rabson, A.B.; Wang, Y.; Shi, Y. Kynurenic acid, an IDO metabolite, controls TSG-6-mediated immunosuppression of human mesenchymal stem cells. Cell Death Differ. 2018, 25, 1209-1223. [CrossRef]

112. Liu, S.; Liu, F.; Zhou, Y.; Jin, B.; Sun, Q.; Guo, S. Immunosuppressive Property of MSCs Mediated by Cell Surface Receptors. Front. Immunol. 2020, 11, 1076. [CrossRef]

113. Galleu, A.; Riffo-Vasquez, Y.; Trento, C.; Lomas, C.; Dolcetti, L.; Cheung, T.S.; von Bonin, M.; Barbieri, L.; Halai, K.; Ward, S.; et al. Apoptosis in mesenchymal stromal cells induces in vivo recipient-mediated immunomodulation. Sci. Transl. Med. 2017, 9. [CrossRef]

114. Preda, M.B.; Neculachi, C.A.; Fenyo, I.M.; Vacaru, A.-M.; Publik, M.A.; Simionescu, M.; Burlacu, A. Short lifespan of syngeneic transplanted MSC is a consequence of in vivo apoptosis and immune cell recruitment in mice. Cell Death Dis. 2021, 12, 1-12. [CrossRef]

115. Boothby, M.; Rickert, R.C. Metabolic Regulation of the Immune Humoral Response. Immunity 2017, 46, 743-755. [CrossRef]

116. Volkov, M.; van Schie, K.A.; van der Woude, D. Autoantibodies and B Cells: The ABC of rheumatoid arthritis pathophysiology. Immunol. Rev. 2020, 294, 148-163. [CrossRef]

117. Shalini, P.U.; Vidyasagar, J.; Kona, L.K.; Ponnana, M.; Chelluri, L.K. In vitro allogeneic immune cell response to mesenchymal stromal cells derived from human adipose in patients with rheumatoid arthritis. Cell. Immunol. 2017, 314, 18-25. [CrossRef] [PubMed] 
118. Vasilev, G.; Ivanova, M.; Ivanova-Todorova, E.; Tumangelova-Yuzeir, K.; Krasimirova, E.; Stoilov, R.; Kyurkchiev, D. Secretory factors produced by adipose mesenchymal stem cells downregulate Th17 and increase Treg cells in peripheral blood mononuclear cells from rheumatoid arthritis patients. Rheumatol. Int. 2019, 39, 819-826. [CrossRef] [PubMed]

119. Zhang, L.; Wang, X.-Y.; Zhou, P.-J.; He, Z.; Yan, H.-Z.; Xu, D.-D.; Wang, Y.; Fu, W.-Y.; Ruan, B.-B.; Wang, S. Use of immune modulation by human adipose-derived mesenchymal stem cells to treat experimental arthritis in mice. Am. J. Transl. Res. 2017, 9, 2595. [PubMed]

120. Liu, X.; Feng, T.; Gong, T.; Shen, C.; Zhu, T.; Wu, Q.; Li, Q.; Li, H. Human umbilical cord mesenchymal stem cells inhibit the function of allogeneic activated V $\gamma 9 \mathrm{~V} \delta 2 \mathrm{~T}$ lymphocytes in vitro. BioMed Res. Int. 2015, 2015, 1-10. [CrossRef] [PubMed]

121. Martinet, L.; Fleury-Cappellesso, S.; Gadelorge, M.; Dietrich, G.; Bourin, P.; Fournié, J.J.; Poupot, R. A regulatory cross-talk between V $\gamma 9 \mathrm{~V} \delta 2 \mathrm{~T}$ lymphocytes and mesenchymal stem cells. Eur. J. Immunol. 2009, 39, 752-762. [CrossRef]

122. El-Jawhari, J.; El-Sherbiny, Y.; Jones, E.; McGonagle, D. Mesenchymal stem cells, autoimmunity and rheumatoid arthritis. QJM 2014, 107, 505-514. [CrossRef]

123. Hwang, J.J.; Rim, Y.A.; Nam, Y.; Ju, J.H. Recent Developments in Clinical Applications of Mesenchymal Stem Cells in the Treatment of Rheumatoid Arthritis and Osteoarthritis. Front. Immunol. 2021, 12, 448. [CrossRef]

124. Mulherin, D.; Fitzgerald, O.; Bresnihan, B. Synovial tissue macrophage populations and articular damage in rheumatoid arthritis. Arthritis Rheum. 1996, 39, 115-124. [CrossRef]

125. Udalova, I.A.; Mantovani, A.; Feldmann, M. Macrophage heterogeneity in the context of rheumatoid arthritis. Nat. Rev. Rheumatol. 2016, 12, 472-485. [CrossRef]

126. Shapouri-Moghaddam, A.; Mohammadian, S.; Vazini, H.; Taghadosi, M.; Esmaeili, S.A.; Mardani, F.; Seifi, B.; Mohammadi, A.; Afshari, J.T.; Sahebkar, A. Macrophage plasticity, polarization, and function in health and disease. J. Cell. Physiol. 2018, 233, 6425-6440. [CrossRef]

127. Shin, T.-H.; Kim, H.-S.; Kang, T.-W.; Lee, B.-C.; Lee, H.-Y.; Kim, Y.-J.; Shin, J.-H.; Seo, Y.; Choi, S.W.; Lee, S. Human umbilical cord blood-stem cells direct macrophage polarization and block inflammasome activation to alleviate rheumatoid arthritis. Cell Death Dis. 2016, 7, e2524. [CrossRef]

128. Steffen, U.; Schett, G.; Bozec, A. How autoantibodies regulate osteoclast induced bone loss in rheumatoid arthritis. Front. Immunol. 2019, 10, 1483. [CrossRef]

129. Bozec, A.; Luo, Y.; Engdahl, C.; Figueiredo, C.; Bang, H.; Schett, G. Abatacept blocks anti-citrullinated protein antibody and rheumatoid factor mediated cytokine production in human macrophages in IDO-dependent manner. Arthritis Res. Ther. 2018, 20, 1-9. [CrossRef]

130. Garimella, M.G.; Kour, S.; Piprode, V.; Mittal, M.; Kumar, A.; Rani, L.; Pote, S.T.; Mishra, G.C.; Chattopadhyay, N.; Wani, M.R. Adipose-derived mesenchymal stem cells prevent systemic bone loss in collagen-induced arthritis. J. Immunol. 2015, 195, 5136-5148. [CrossRef]

131. Worbs, T.; Hammerschmidt, S.I.; Förster, R. Dendritic cell migration in health and disease. Nat. Rev. Immunol. 2017, 17, 30-48. [CrossRef]

132. Han, Y.; Li, X.; Zhou, Q.; Jie, H.; Lao, X.; Han, J.; He, J.; Liu, X.; Gu, D.; He, Y.; et al. FTY720 Abrogates Collagen-Induced Arthritis by Hindering Dendritic Cell Migration to Local Lymph Nodes. J. Immunol. 2015, 195, 4126-4135. [CrossRef]

133. Shi, B.; Qi, J.; Yao, G.; Feng, R.; Zhang, Z.; Wang, D.; Chen, C.; Tang, X.; Lu, L.; Chen, W. Mesenchymal stem cell transplantation ameliorates Sjögren's syndrome via suppressing IL-12 production by dendritic cells. Stem Cell Res. Ther. 2018, 9, 1-10. [CrossRef]

134. Li, R.; Zhang, Y.; Zheng, X.; Peng, S.; Yuan, K.; Zhang, X.; Min, W. Synergistic suppression of autoimmune arthritis through concurrent treatment with tolerogenic DC and MSC. Sci. Rep. 2017, 7, 43188. [CrossRef]

135. Yu, Y.; Yoon, K.A.; Kang, T.W.; Jeon, H.J.; Sim, Y.B.; Choe, S.H.; Baek, S.Y.; Lee, S.; Seo, K.W.; Kang, K.S. Therapeutic effect of long-interval repeated intravenous administration of human umbilical cord blood-derived mesenchymal stem cells in DBA/1 mice with collagen-induced arthritis. J. Tissue Eng. Regen. Med. 2019, 13, 1134-1142. [CrossRef]

136. Liu, L.; Farhoodi, H.P.; Han, M.; Liu, G.; Yu, J.; Nguyen, L.; Nguyen, B.; Nguyen, A.; Liao, W.; Zhao, W. Preclinical Evaluation of a Single Intravenous Infusion of hUC-MSC (BX-U001) in Rheumatoid Arthritis. Cell Transplant. 2020, 29, 0963689720965896. [CrossRef]

137. Gonzalo-Gil, E.; Pérez-Lorenzo, M.J.; Galindo, M.; de la Guardia, R.D.; López-Millán, B.; Bueno, C.; Menéndez, P.; Pablos, J.L.; Criado, G. Human embryonic stem cell-derived mesenchymal stromal cells ameliorate collagen-induced arthritis by inducing host-derived indoleamine 2, 3 dioxygenase. Arthritis Res. Ther. 2016, 18, 1-9. [CrossRef]

138. Liu, R.; Li, X.; Zhang, Z.; Zhou, M.; Sun, Y.; Su, D.; Feng, X.; Gao, X.; Shi, S.; Chen, W. Allogeneic mesenchymal stem cells inhibited $\mathrm{T}$ follicular helper cell generation in rheumatoid arthritis. Sci. Rep. 2015, 5, 12777. [CrossRef]

139. Petrelli, A.; Van Wijk, F. CD8+ T cells in human autoimmune arthritis: The unusual suspects. Nat. Rev. Rheumatol. 2016, 12, 421-428. [CrossRef]

140. Vohra, M.; Sharma, A.; Bagga, R.; Arora, S.K. Human umbilical cord-derived mesenchymal stem cells induce tissue repair and regeneration in collagen-induced arthritis in rats. J. Clin. Transl. Res. 2020, 6, 203.

141. Lopez-Santalla, M.; Mancheño-Corvo, P.; Menta, R.; Lopez-Belmonte, J.; DelaRosa, O.; Bueren, J.A.; Dalemans, W.; Lombardo, E.; Garin, M.I. Human adipose-derived mesenchymal stem cells modulate experimental autoimmune arthritis by modifying early adaptive T cell responses. Stem Cells 2015, 33, 3493-3503. [CrossRef] 
142. Liu, Y.; Mu, R.; Wang, S.; Long, L.; Liu, X.; Li, R.; Sun, J.; Guo, J.; Zhang, X.; Guo, J. Therapeutic potential of human umbilical cord mesenchymal stem cells in the treatment of rheumatoid arthritis. Arthritis Res. Ther. 2010, 12, 1-13. [CrossRef]

143. Chen, Q.-H.; Wu, F.; Liu, L.; Chen, H.-b.; Zheng, R.-Q.; Wang, H.-L.; Yu, L.-N. Mesenchymal stem cells regulate the Th17/Treg cell balance partly through hepatocyte growth factor in vitro. Stem Cell Res. Ther. 2020, 11, 1-11. [CrossRef]

144. Haikal, S.M.; Abdeltawab, N.F.; Rashed, L.A.; El-Galil, A.; Tarek, I.; Elmalt, H.A.; Amin, M.A. Combination therapy of mesenchymal stromal cells and interleukin-4 attenuates rheumatoid arthritis in a collagen-induced murine model. Cells $2019,8,823$. [CrossRef] [PubMed]

145. Jones, F.K.; Stefan, A.; Kay, A.G.; Hyland, M.; Morgan, R.; Forsyth, N.R.; Pisconti, A.; Kehoe, O. Syndecan-3 regulates MSC adhesion, ERK and AKT signalling in vitro and its deletion enhances MSC efficacy in a model of inflammatory arthritis in vivo. Sci. Rep. 2020, 10, 20487. [CrossRef] [PubMed]

146. Lopez-Santalla, M.; Fernandez-Perez, R.; Garin, M.I. Mesenchymal stem/stromal cells for rheumatoid arthritis treatment: An update on clinical applications. Cells 2020, 9, 1852. [CrossRef] [PubMed]

147. Hu, C.; Li, L. Preconditioning influences mesenchymal stem cell properties in vitro and in vivo. J. Cell. Mol. Med. 2018, 22, 1428-1442. [CrossRef] [PubMed]

148. Raziyeva, K.; Smagulova, A.; Kim, Y.; Smagul, S.; Nurkesh, A.; Saparov, A. Preconditioned and genetically modified stem cells for myocardial infarction treatment. Int. J. Mol. Sci. 2020, 21, 7301. [CrossRef] [PubMed]

149. Saparov, A.; Ogay, V.; Nurgozhin, T.; Jumabay, M.; Chen, W.C. Preconditioning of human mesenchymal stem cells to enhance their regulation of the immune response. Stem Cells Int. 2016, 2016, 1-10. [CrossRef]

150. Mansurov, N.; Chen, W.C.; Awada, H.; Huard, J.; Wang, Y.; Saparov, A. A controlled release system for simultaneous delivery of three human perivascular stem cell-derived factors for tissue repair and regeneration. J. Tissue Eng. Regen. Med. 2018, 12, e1164-e1172. [CrossRef]

151. de Cássia Noronha, N.; Mizukami, A.; Caliári-Oliveira, C.; Cominal, J.G.; Rocha, J.L.M.; Covas, D.T.; Swiech, K.; Malmegrim, K.C. Priming approaches to improve the efficacy of mesenchymal stromal cell-based therapies. Stem Cell Res. Ther. 2019, 10, 1-21.

152. Park, J.S.; Suryaprakash, S.; Lao, Y.-H.; Leong, K.W. Engineering mesenchymal stem cells for regenerative medicine and drug delivery. Methods 2015, 84, 3-16. [CrossRef]

153. Lim, J.-Y.; Im, K.-I.; Lee, E.-S.; Kim, N.; Nam, Y.-S.; Jeon, Y.-W.; Cho, S.-G. Enhanced immunoregulation of mesenchymal stem cells by IL-10-producing type 1 regulatory T cells in collagen-induced arthritis. Sci. Rep. 2016, 6, 26851. [CrossRef]

154. Petrenko, Y.; Syková, E.; Kubinová, Š. The therapeutic potential of three-dimensional multipotent mesenchymal stromal cell spheroids. Stem Cell Res. Ther. 2017, 8, 1-9. [CrossRef]

155. Bartosh, T.J.; Ylöstalo, J.H.; Bazhanov, N.; Kuhlman, J.; Prockop, D.J. Dynamic compaction of human mesenchymal stem/precursor cells into spheres self-activates caspase-dependent IL1 signaling to enhance secretion of modulators of inflammation and immunity (PGE2, TSG6, and STC1). Stem Cells 2013, 31, 2443-2456. [CrossRef]

156. Zimmermann, J.A.; Mcdevitt, T.C. Pre-conditioning mesenchymal stromal cell spheroids for immunomodulatory paracrine factor secretion. Cytotherapy 2014, 16, 331-345. [CrossRef]

157. Contreras, R.A.; Figueroa, F.E.; Djouad, F.; Luz-Crawford, P. Mesenchymal Stem Cells Regulate the Innate and Adaptive Immune Responses Dampening Arthritis Progression. Stem Cells Int. 2016, 2016, 3162743. [CrossRef]

158. Rashedi, I.; Gómez-Aristizábal, A.; Wang, X.H.; Viswanathan, S.; Keating, A. TLR3 or TLR4 activation enhances mesenchymal stromal cell-mediated Treg induction via Notch signaling. Stem Cells 2017, 35, 265-275. [CrossRef]

159. Kim, D.S.; Lee, W.H.; Lee, M.W.; Park, H.J.; Jang, I.K.; Lee, J.W.; Sung, K.W.; Koo, H.H.; Yoo, K.H. Involvement of TLR3-dependent PGES expression in immunosuppression by human bone marrow mesenchymal stem cells. Stem Cell Rev. Rep. 2018, 14, 286-293. [CrossRef]

160. Ghaffary, E.M.; Froushani, S.M.A. Immunomodulatory benefits of mesenchymal stem cells treated with caffeine in adjuvantinduced arthritis. Life Sci. 2020, 246, 117420. [CrossRef]

161. Chen, H.; Ge, H.-a.; Wu, G.-b.; Cheng, B.; Lu, Y.; Jiang, C. Autophagy prevents oxidative stress-induced loss of self-renewal capacity and stemness in human tendon stem cells by reducing ROS accumulation. Cell. Physiol. Biochem. 2016, 39, $2227-2238$. [CrossRef]

162. Xu, L.; Wang, X.; Wang, J.; Liu, D.; Wang, Y.; Huang, Z.; Tan, H. Hypoxia-induced secretion of IL-10 from adipose-derived mesenchymal stem cell promotes growth and cancer stem cell properties of Burkitt lymphoma. Tumor Biol. 2016, 37, 7835-7842. [CrossRef]

163. Rhijn, R.-V.; Mensah, F.K.; Korevaar, S.S.; Leijs, M.J.; van Osch, G.J.; IJzermans, J.N.; Betjes, M.G.; Baan, C.C.; Weimar, W.; Hoogduijn, M.J. Effects of hypoxia on the immunomodulatory properties of adipose tissue-derived mesenchymal stem cells. Front. Immunol. 2013, 4, 203.

164. Ogay, V.; Sekenova, A.; Li, Y.; Issabekova, A.; Saparov, A. The Therapeutic Potential of Mesenchymal Stem Cells in the Treatment of Atherosclerosis. Curr. Stem Cell Res. Ther. 2021, 16, 897-913. [CrossRef]

165. Gorgun, C.; Ceresa, D.; Lesage, R.; Villa, F.; Reverberi, D.; Balbi, C.; Santamaria, S.; Cortese, K.; Malatesta, P.; Geris, L.; et al. Dissecting the effects of preconditioning with inflammatory cytokines and hypoxia on the angiogenic potential of mesenchymal stromal cell (MSC)-derived soluble proteins and extracellular vesicles (EVs). Biomaterials 2021, 269, 120633. [CrossRef] 
166. Zhang, Z.; Yang, C.; Shen, M.; Yang, M.; Jin, Z.; Ding, L.; Jiang, W.; Yang, J.; Chen, H.; Cao, F.; et al. Autophagy mediates the beneficial effect of hypoxic preconditioning on bone marrow mesenchymal stem cells for the therapy of myocardial infarction. Stem Cell Res. Ther. 2017, 8, 89. [CrossRef]

167. Wobma, H.M.; Kanai, M.; Ma, S.P.; Shih, Y.; Li, H.W.; Duran-Struuck, R.; Winchester, R.; Goeta, S.; Brown, L.M.; Vunjak-Novakovic, G. Dual IFN- $\gamma$ /hypoxia priming enhances immunosuppression of mesenchymal stromal cells through regulatory proteins and metabolic mechanisms. J. Immunol. Regen. Med. 2018, 1, 45-56. [CrossRef]

168. Noone, C.; Kihm, A.; English, K.; O'Dea, S.; Mahon, B.P. IFN- $\gamma$ stimulated human umbilical-tissue-derived cells potently suppress NK activation and resist NK-mediated cytotoxicity in vitro. Stem Cells Dev. 2013, 22, 3003-3014. [CrossRef]

169. Carvalho, A.É.S.; Sousa, M.R.R.; Alencar-Silva, T.; Carvalho, J.L.; Saldanha-Araujo, F. Mesenchymal stem cells immunomodulation: The road to IFN- $\gamma$ licensing and the path ahead. Cytokine Growth Factor Rev. 2019, 47, 32-42. [CrossRef]

170. Philipp, D.; Suhr, L.; Wahlers, T.; Choi, Y.H.; Paunel-Görgülü, A. Preconditioning of bone marrow-derived mesenchymal stem cells highly strengthens their potential to promote IL-6-dependent M2b polarization. Stem Cell Res. Ther. 2018, 9, 286. [CrossRef]

171. Redondo-Castro, E.; Cunningham, C.; Miller, J.; Martuscelli, L.; Aoulad-Ali, S.; Rothwell, N.J.; Kielty, C.M.; Allan, S.M.; Pinteaux, E. Interleukin-1 primes human mesenchymal stem cells towards an anti-inflammatory and pro-trophic phenotype in vitro. Stem Cell Res. Ther. 2017, 8, 79. [CrossRef]

172. Chinnadurai, R.; Copland, I.B.; Patel, S.R.; Galipeau, J. IDO-independent suppression of T cell effector function by IFN- $\gamma$-licensed human mesenchymal stromal cells. J. Immunol. 2014, 192, 1491-1501. [CrossRef]

173. Sivanathan, K.N.; Rojas-Canales, D.M.; Hope, C.M.; Krishnan, R.; Carroll, R.P.; Gronthos, S.; Grey, S.T.; Coates, P.T. Interleukin17A-Induced Human Mesenchymal Stem Cells Are Superior Modulators of Immunological Function. Stem Cells 2015, 33, 2850-2863. [CrossRef] 